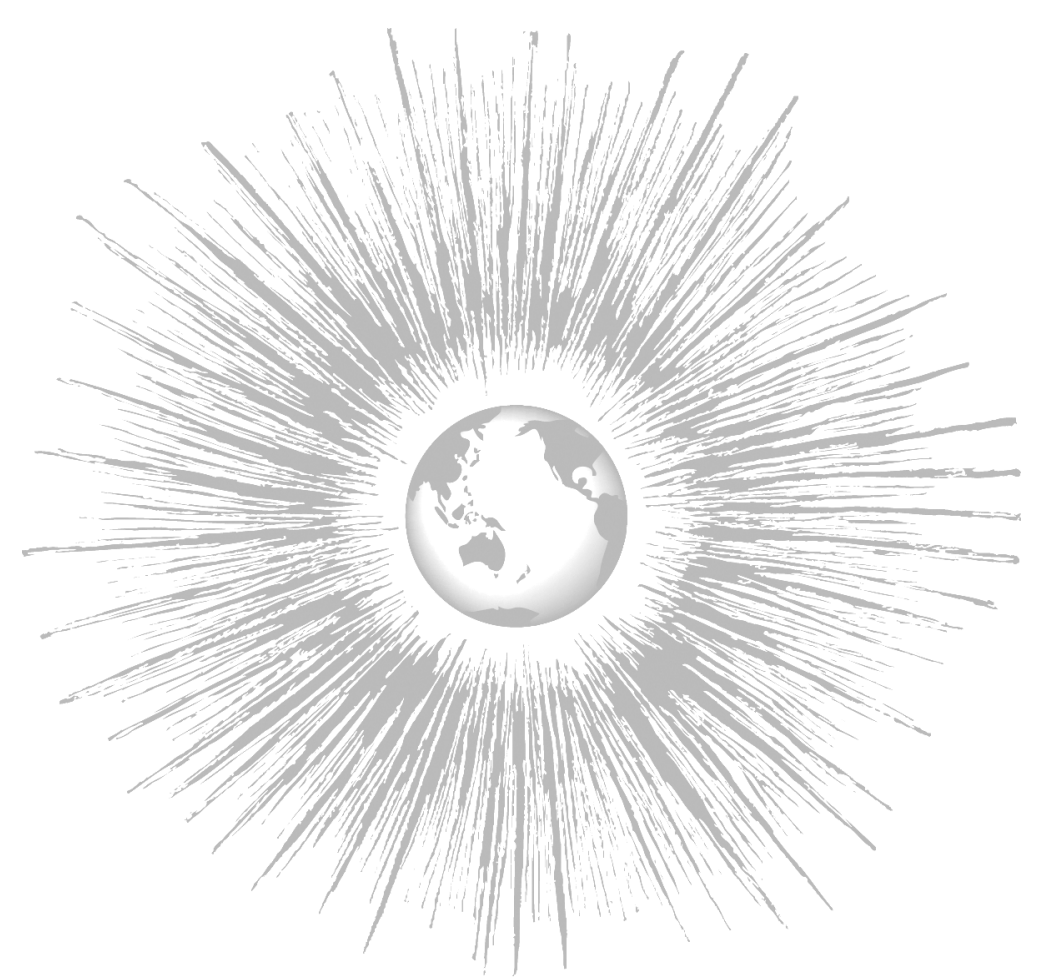

ABSTRACT:

Following up on an earlier paper demonstrating statistically significant relationship between measures of recurring political-economic crises (hinterland incursions, trad collapses, economic contractions, and regime transitions) and a measure of climate deterioration (the interaction of falling Tigris Euphrates river levels and years of warming/ drying), the inter-relationships among these variables are examined more closely for the 3400-IOOO BCE period. Theoretically focused on a test of Tainter's diminishing marginal return theory of societal collapse, additiona indicators are introduced encompassing pop ulation (urban population size, urban population growth rate) as a proxy for diminishing

\section{Complexity, Diminishing Marginal Returns, and Serial Mesopotamian Fragmentation*}

William R. Thompson

Dolution toward greater complexity in the ancient world was rarely characterized by a linear trend. ${ }^{1}$ Ancient societies would become more centralized and complex but only to a point before fragmenting into local systems. Years later movement toward greater centralization and complexity resumed until, once again, some sort of check or limit was experienced and fragmentation reigned dominant. In some regions, these oscillations occurred often enough to qualify as highly irregular cycles of order and disorder.

Why might this have been the case? Is it possible to generalize ancient cyclical processes of entropy? Or, must we be content with painfully piecing together rudimentary descriptive understandings of what might have happened in preliterate and dark ages? The awkward reconstruction of what may have transpired cannot be avoided. We need descriptive histories. But we also need efforts to move beyond description that may, if nothing else, sharpen our search

William R. Thompson

Department of Political Science

Indiana University

Bloomington, IN 47405

wthompso@indiana.edu

http://www.indiana.edu/ iupolsci/bio thompson.html

* An earlier version of this article was presented at a meeting of the Working Group on Analyzing Complex Macrosystems as Dynamic Networks, April 28-May 2, 2004, Santa Fe Institute, Santa Fe, New Mexico. I am indebted for a number of good ideas suggested in the discussion and later, including ones from Robert McC Adams, Christopher Chase-Dunn, Peter Turchin, Douglas White, and Henry Wright. Special thanks are owed to Henry Wright for his line-by-line critique to which I might do justice in a few more decades of further data collection.

1. There is, of course, no reason to assume that evolutionary developments cannot move in the direction of reduced complexity. See, for example, Dewar and Wright (I993).

JOURNAL OF WORLD-SYSTEMS RESEARCH, $\mathrm{X}$, 3, FALL 2004, 6I3-652 http://jwsr.ucr.edu/

ISSN $1076-156 \mathrm{X}$

(C) 2004 William R. Thompson 
for improved description. It also, as Adams (1988: 2I) points out, helps clarify our understanding of evolutionary processes that do not always move progressively. ${ }^{2}$ One of the main assumptions of this paper is that it is possible to model cycles of centralization and complexity. Ancient Mesopotamia (3400-1000 BCE) provides the focal point. Eleven variables encompassing political-economic crisis, climate deterioration, urban population, and centralization/ fragmentation are developed and their inter-relationships examined empirically according to a set of expectations predicated in part on Joseph Tainter's (1988) theory of diminishing marginal returns. The empirical outcome generates support for this theory. It also helps clarify the role of traditional shocks such as "barbarian" incursions, climate deterioration, and trade collapses that were also characterized by irregular cycles of occurrence.

\section{EXPLAINING MESOPOTAMIAN DECLINE AND FRAGMENTATION}

Lower Mesopotamia is usually credited with pioneering a number of significant firsts-including the urbanization revolution, the secondary products revolution (including transportation), writing, possibly the first phalanx, and, more clearly, the first clear-cut imperial expansion (Sargon's Akkad). It was probably not the first ancient society to collapse or disintegrate. Lower Mesopotamia, however, probably was the first ancient society to initiate a sequential cycle oscillating between periods of centralization and periods of fragmentation. It is possible that this cycle began as early as the Ubaid $5^{\text {th }}$ millennium (Stein 1999) but it clearly was manifested in the $4^{\text {th }}$ millennium's political-economic expansion of the Uruk era and its subsequent retrenchment toward the end of that millennium. The emergence of Akkad in the mid-230os re-centralized Lower Mesopotamia briefly until it fell apart under attack from Gutian highlanders in the last centuries of the $3^{\text {rd }}$ millennium. Ur III created another brief era of centralization before it too disintegrated in 2000 . Hammurabi managed to recreate an imperial center in the Amorite Old Babylonian $18^{\text {th }}$ century, but it too disappeared within a short period of time. What is usually portrayed as a relatively weak Kassite empire took form by the I40os. Yet it too had vanished by the end of the $12^{\text {th }}$ century. ${ }^{3}$

2. For more contemporary interests in modeling decline phenomena, see Cipolla (1970), Gilpin (I98I), and Rasler and Thompson (I994).

3. One might continue the cycle through the Assyrian iteration in the $\mathrm{I}^{\text {st }}$ millennium if it were not for the customary existence of a I200-I000 BCE benchmark for the end of the ancient world in western Eurasia.
Why then did Mesopotamian history repeat itself five or six times within the span of several millennia? Of course, we need to demonstrate that behavior repeated itself in each iteration of centralization and fragmentation, as opposed to assuming it. One way to address this question is to ask whether it is possible to model repetitive fragmentation theoretically and empirically in the ancient Mesopotamian context. If it cannot be modeled successfully, we might conclude that fragmentation behavior did not repeat itself. But if we can model the phenomenon, we will at least have empirical evidence for repetitive behavior.

As it happens, explanations of Mesopotamian decline and fragmentation take a finite number of shapes. The most well developed and fundamental strand is probably the argument that agricultural intensification, especially when abetted by political centralization, led to over-irrigation, soil salinity, a decline in agricultural productivity, and political-economic instability (Jacobsen and Adams 1958; Gibson 1974; Maekawa 1984; Adams 1981; Algaze 1986; Hole 1994; Redman 1999). Political regimes in a fairly fragile and arid ecosystem could not be expected to survive the erosion of one of its most basic economic resources.

A second theme in the literature is that the political unification of Mesopotamian cities did not come naturally. They were accustomed to some degree of autonomy and, while they might be coercively integrated in a larger state from time to time, the tendency was to return to local orientations whenever the opportunity arose (Edzard 1967b; Yoffee 1979, 1988). In this respect, it is not only disintegration that needs to be explained but rather also the occasional, temporary, and essentially aberrational successes at integration or unification.

Seemingly complementary to both arguments are emphases for and against various kinds of environmental shocks—a slight shift in rainfall (Postgate 1992), river water scarcity (Butzer 1995; Gasche et al. 1998), catastrophic natural disasters (Weiss and Courty 1993; Weiss et al. 1993; Weiss 2000; Butzer 1997; Matthews 2003), barbarian intrusions (Speiser 1952; Buccellati 1966; Edzard 1967a, 1967b; Diakonoff 1969; Oates 1979; Yoffee 1988; Lupton 1996 $)^{4}$; defeat in warfare (Edzard 1967b; Postgate 1977), or a loss of trade networks (Ekholm 1980; Potts 1994). Often, authors have argued that these shocks were compounded by appearing simultaneously. An example is found in Edzard (1967b: 157),

4. See Bronson (I988: 213) for his very useful delineation of vultures (scavengers that wait until the victim is dead), jackals (scavengers that prey on the weak), wolves (predators that facilitate the development of weakness), and tigers (predators that can kill the strongest prey) as four different roles intrusive outsiders can play in bringing down states. 
...What forces brought [the empire of Ur III] to an end? The unquenchable and ever renewed particularism of the Babylonian cities, for one thing, and their unwillingness to acquiesce in the rule of one of their own number for any length of time. Then, too, the increasing influx of Semitic nomads, i.e. the migration of the Amorites. Finally, the always unstable relations between Babylonia and Elam, a country that, for all its willingness to absorb much of Babylonian civilization, refused to be assimilated to it entirely.

Thus, things tend to fall apart when too many internal and external problems are encountered at the same time.

Interestingly, contemporary Sumerian poetry (roughly early and millennium BCE) offers a multivariate view of Mesopotamian decline that is capable of summarizing many of the elements emphasized by analysts several millennia later. Putting aside the principal agency of disruptive gods, we are told about problems with the flow of the Tigris and Euphrates rivers, governmental breakdown, deurbanization, hinterland incursions (Simaski), foreign attacks (Elam), regime transitions, and agrarian productivity.

After An had frowned upon all the lands,

After Enlil had looked favorably on an enemy land,

After Nintu had scattered the creatures that she had created,

After Enki had altered [the course of] the Tigris and Euphrates,

After Utu had cast his curse on the roads and highways,

In order to forsake the divine decrees of Sumer, to change its [preordained] plans,

To alienate the [divine] decrees of the reign of kingship of Ur,

To defile the Princely Son in his [temple] Ekisnugal,

To break up the unity of the people of Nanna, numerous as ewes,

To change the food offerings of $U r$, the shrine of magnificent food offerings,

That its people no longer dwell in their quarters, that they be given over [to live] in an inimical place,

That [the soldiers of] Simaski and Elam, the enemy, dwell in their place,

That its shepherd be captured by the enemy, all alone,

That Ibbi-Sin be taken to the land of Elam in fetters, ....

That the hoe attack not the fertile fields, that seed not be planted in the ground,

That the sound of the song of the one tending the oxen not resound on the plain,

That butter and cheese not be made in the cattle pen, that dung not be laid on the ground, .....

(lines 22-44 from Lamentation over Sumer and Ur, in Michalowski 1989, cited in Postgate 1992: 295).

Yet explanations of decline that feature emphases on intrusive barbarians, resource shortages, or, even worse, climate deterioration have tended to be marginalized by the search for more theoretically pleasing and more general models. As social scientists, we are not satisfied with attributing decline at time $\mathrm{x}$ to soil salinity and time $\mathrm{x}+\mathrm{I}$ to barbarian attacks. There are simply too many instances of decline to explain in descriptive terms alone. Otherwise, we end up spinning serial stories of what we think transpired-a task best left to historians who specialize in this approach. There is also the underlying suspicion that each episode of decline may not be so unique in terms of the factors that appear to have brought about the downfall of order. Many of the same ingredients seem to keep cropping up. Moreover, we also know that rise and decline cycles have been widespread throughout the ancient world (Marcus 1998). ${ }^{5}$ As a consequence, we are encouraged to seek more general explanations of what has gone on in the past.

Earlier, however, I have argued that the wholesale rejection of some traditional explanations-especially those involving climate and incursions-is tantamount to throwing the baby out with the bathwater. ${ }^{6}$ An empirical examination of Mesopotamia and Egypt for the 4000-I000 BCE period shows a statistically significant relationship between climate deterioration and river level fluctuations, hinterland incursions, trade collapses, and political regime changes. ${ }^{7}$ So, not only did these problems occur, they also occurred in intermittent but serial clusters or constellations of political-economic crises. We should be reluctant to privilege one part of the constellation over the other parts, but we should be even more reluctant to dispense with them altogether if they help explain periodic fragmentation.

In the same article, Tainter (1988) was used as a presentation foil of sorts. Tainter's book comparing and evaluating explanations of complexity breakdowns has been well received, and justifiably so. One of its features is a quite strong rejection of traditional explanations for decline which are dismissed variously as illogical, sometimes unsubstantiated, and/or often inadequate. Instead, Tainter advances a more general argument that emphasizes diminishing marginal returns to investing in greater complexity. Thompson (forthcoming-a) made no attempt to test or reject this more general explanation. Instead, the argument was that the constellation of crises might be expected to accelerate marginal return trajectories and, in that sense, information on the more tra-

5. Whether whatever is capable of explaining Mesopotamian fragmentation can also account for, say, Mesoamerican fragmentation is another challenge best left to other analyses.

6. See Thompson (forthcoming-a).

7. The one exception was that no statistically significant relationship was found for climate deterioration and economic contractions. 
ditional-type crises should not be rejected prematurely. Three research agenda items, therefore, are left undone. One involves attempting to assess, and possibly to integrate, Tainter's more general argument with what I am referring to as the constellation of crises. Attempting this objective requires more initial theoretical consideration about explanatory compatibilities. Some attempt must also be made to develop an appropriate index of marginal returns. A second objective entails further exploration of the relationships among the indicators previously examined (climate change, river levels, governmental change, economic contraction, hinterland incursions, and trade collapses). The earlier effort was focused on assessing overall statistical significance and the relationships between climate change and various types of crisis. Now, we have an opportunity to look more closely at the relationships that appear to exist among all of the crisis and climate indicators, as well as a new index developed to tap Tainter's marginal return emphasis. Finally, a third objective is to examine directly and empirically Mesopotamian propensities toward centralization and fragmentation, in the context of relationships that prevail among crisis, climate, and marginal returns. Are they all related closely, only loosely, or not at all in the specific Mesopotamian case?

\section{TAINTER'S DIMINISHING MARGINAL RETURN THEORY}

Critical to the objectives of this paper is an articulation of Tainter's diminishing marginal return theory. I am not aware that it is formalized explicitly anywhere. Thus, what follows is my interpretation of his argument as expressed in the 1988 book. Three assumptions appear to be most critical to the argument:

I. Societies are problem-solving organizations that require resources and energy for their maintenance and growth.

2. Societies evolve into more complex socio-political organizations as various subsystems become more interdependent in meeting the demand for resource exploitation.

3. Resources that are easiest and least expensive to exploit are first utilized until their exhaustion requires a shift to more costly resources that do not necessarily yield a higher marginal return in productivity.

Tainter's assumptions delineate specific understandings of the concepts of evolution and complexity. Society is viewed as being oriented toward solving minor and major problems that are constantly emerging, although sometimes they emerge abruptly and without warning. Solving problems requires the investment and expenditure of resources. Some of these resources are easily accessible and will be the ones first utilized. However, once they have been exhausted, less accessible resources may be found but they will be more costly and the benefits associated with them will not necessarily be commensurate with the rising costs. Costly or otherwise, expanding problem solving involves extracting resources from other subsystems, as well as strategies that often seek to impose political and other controls on these other subsystems. In the process, the various subsystems (political, economic, social, military, energy, and so forth) grow increasingly interdependent and, to the extent that this occurs, the society grows more complex.

For instance, it is often argued that sedentary agriculture in Mesopotamia required irrigation and extensive labor resources to keep the irrigation canals open. Managing this strategy required political hierarchy, bureaucracy, and religious sanction. Protecting the agrarian community required military capabilities, more political hierarchy, and bureaucracy. An expanding population implied the need for greater agrarian productivity which meant more irrigation and labor. Urbanization and an expanded division of labor would increase the demands on agrarian productivity even more so.

The assumptions lay the groundwork for four generalizations that serve as the core statement of the diminishing marginal return theory:

I. Societies constantly encounter problems that require increased investment of resources merely to maintain the status quo.

2. As continued investment in complexity yields a declining marginal return, societies are increasingly likely to experience both major new problems requiring solution and an absence of resource reserves to exploit for problem solving-thereby further weakening the society's ability to respond to problems.

3. As declining marginal returns make further complexity increasingly less attractive for problem solving, a society's sociopolitical organization is likely to be reduced to a less complex level sustainable by local resources.

4. Technological innovation and new energy subsidies can slow or postpone the long-term movement toward diminishing returns at the margins.

A state of equilibrium in the problem solving-resource investment/expenditure equation is most unlikely since an escalating demand for more resources is probable just to deal with old problems. Add the strong likelihood of new problems emerging and one can expect the necessary resources to deal with them to become more costly and less easily obtainable. There are also limits on society's ability to accumulate resource reserves for rainy days or, in the Mesopotamian case, days without rain. The resources at hand can only be stretched 
so far. If the new problems exceed the resource base, the ability to deal with both old and new problems will be reduced. ${ }^{8}$

In this context, the benefits derived from intensified complexity (greater subsystemic interdependence) will begin to decline vis-à-vis the escalating costs of resource mobilization. Not only will resource extraction become more difficult, resistance to resource extraction will also become greater. Local loyalties will re-emerge as more important than vanishing loyalties to a decaying and impotent central authority. The central authority may persist as some form of political fiction, it may simply cease to function at all, or it might be taken over at least partially by external invaders.

One way to look at this argument is that it is an explanation of entropic tendencies toward disorder. Entropy is not inevitable in the short term. It can be put off by creating new resources via technological innovation or new sources of energy to fuel technology. External conquest, conceivably, can be utilized to gain access to resources that might otherwise be denied or offered at too high a price. ${ }^{9}$ In the ancient world, external conquest was a more feasible strategy than relying on technological innovation or new sources of energy. Yet even external conquest could not be successful for an infinite period of time. All ancient imperial expansions proceeded to certain points that may well have exceeded their capabilities but none developed an ability to expand all that far or continuously. In the absence of innovation, new energy sources, or new resources via conquest, other things being equal, we are back to approaching a situation in which the marginal return of new resource investments begins to decline. In these circumstances, societies become more vulnerable to collapse which, in Tainter's framework, means a fragmentation into more particularistic communities. The implication is that decentralization may lead to improved solutions to societal problems - at least in comparison to the failed efforts of the older centralized strategy.

It is also clear why Tainter might be impatient with attempts to explain decline in terms of climate deterioration, barbarian intrusions, or even agricultural productivity problems. Aridity, hinterland attacks, and salinization

8. Writing on Mayan decline, Culbert (I988: IOI) argues similarly that "when expansion reaches the point at which it can no longer produce new wealth, the administrative structures begin to feed off internal resources, a process that could lead ultimately to collapse.

9. Kaufman (I988:23I) would add the emergence of extraordinary leaders to this list. But unless they are the agents of obtaining new resources and/or conquest, it is not clear that their impact can be anything other than ephemeral. are sources of problems for political and economic decision-makers to solve. In some cases, they succeed in resolving them while, at other times, the problems appear to be, and are, overwhelming. For Tainter, the question is not what the source(s) of the problems are, but how close is the society to reaching a point of diminishing return in its problem solving investments. If the society is close to that point, its vulnerability to being overwhelmed by the onset of policy problems is enhanced. If the society is not close to that point, it may well be able to cope with the problems for some finite period of time. In this respect, the traditional decline emphases can only capture part of the problem. More technically, the explanations remain underspecified as long as they omit the society's capacity to mobilize resources for problem solving while stressing the problems that need to be resolved. ${ }^{10}$

Tainter's theoretical argument is appealing as a parsimonious attempt to encompass a diverse set of situations in general terms that also promises a comprehensive explanation. Problems or stresses are not unimportant but it is difficult to assess their impact without also assessing problem-solving resource foundations. The rub, however, is that the nature of the problems societies confront are more visible and more readily operationalized. Diminishing marginal return situations are more abstract and less easily measured. Given all of the different types of resources that might be relevant to societal problem solving, any attempt to measure marginal returns directly seems unlikely to be successful, let alone imaginable.

That leaves us in a position to (I) take the theory as applicable on the basis of faith, (2) devise a comprehensive battery of tests that permit us to assess how much goes unexplained-and, therefore, might be attributable to diminishing marginal returns - when we look at the more obvious societal problems, or (3) develop some type of indirect index. The first approach is not very appealing. The second research strategy is far more common in testing theories but still depends on some leaps of faith in identifying the nature of what goes unexplained. The third tack is by far the most preferable approach of the three.

It may be that there is no overt indicator that would work equally well in all settings. One indicator, however, that seems highly applicable to ancient Mesopotamia is population. The Malthusian assumption is that population should be highly sensitive to carrying capacity. As an ancient society approached situations in which the net benefits from investing resources in coping with

10. Tainter (2000) is somewhat less dismissive of the explanatory role of stresses. He acknowledges that they may be characterized by complicated lags thereby making their impact less obvious. 
Figure 1 - Consolidation \& Breakdown in Mesopotamia

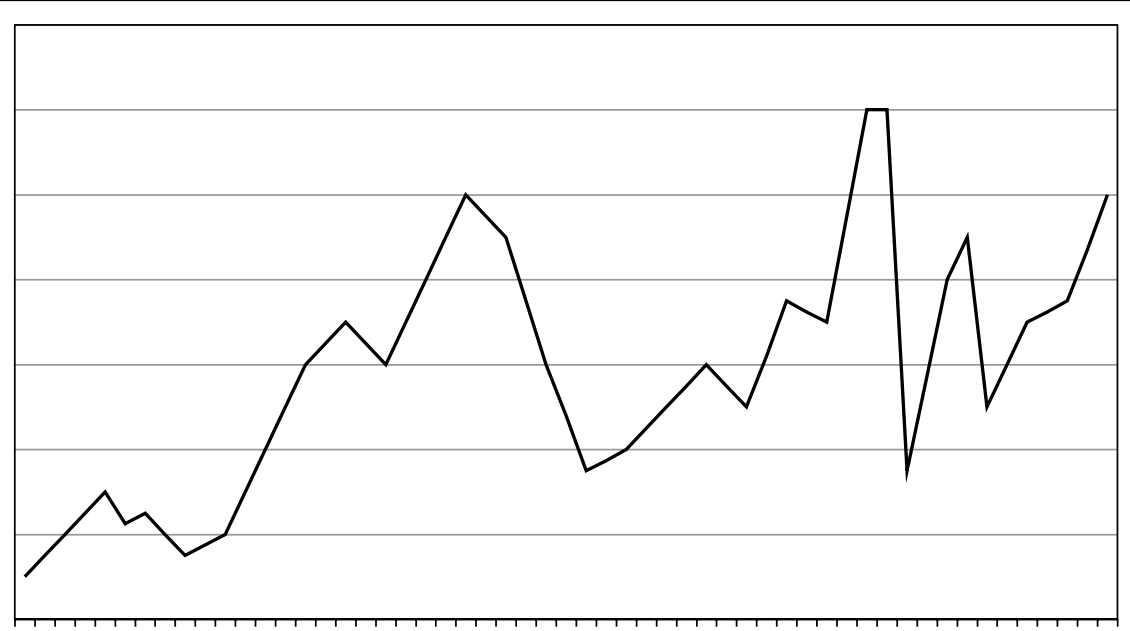

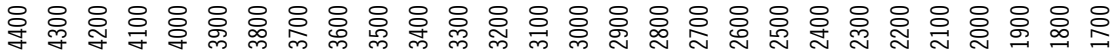

problems began to diminish, we should anticipate slowing birth rates as family expectations grow more dismal and/or, probably, accelerating death rates from famine, war, and disease. The net outcome is slower or even negative population growth. If there is no societal problem with diminishing marginal returns, the net outcome is likely to be positive population growth. If indeed marginal returns have an inverted $U$ trajectory over time, we should expect population growth to share a similar trajectory. Population growth should be high initially and then drop off as resources for problem solving become more costly. Thus, "all" we need to test the applicability of Tainter's theory to the Mesopotamian case are indicators of population growth, centralization and fragmentation, as well as possible sources of stress (in the Tainter framework) such as climate deterioration, economic vicissitudes, governmental and trade collapses, and incursions of peoples from the mountains and desert. While it is fair to say that ancient Mesopotamia has not been the subject of extensive social science modeling, the data that are essential to modeling are not as impossible to come by as some might think. Describing and justifying a set of appropriate indicators is the mission of the next section.

\section{INDICATORS}

\section{Centralization and Fragmentation}

Marcus (1998) demonstrates a widespread tendency toward repetitive cycles of consolidation around the expansion of a single state and its dissolution and replacement by "trough" periods of decentralization. Her cases include Mesoamerican, Andean, Egyptian, Aegean, and, most important for our immediate purposes, Mesopotamian histories. Her attempt to capture this cycle in the Mesopotamian case is replicated in Figure I. Part of her argument is that periods of decentralization are not always devoid of attempts at unification but that their attempts are not as successful as a few more prominent examples that managed to accomplish a discernible amount of unification. Hence her Mesopotamian plot contains several large surges (Uruk, Akkad, Ur III, and Hammurabi's Old Babylonian empire) interspersed with less successful bumps that failed.

Of course, her operationalization is subjectively freehand. While the outcome is attractive, we need something more objective for empirical analysis. An obvious possibility is Taagapera's (1978a, 1978b) data on imperial area estimates. Expanding empires are captured in growing area under imperial control; declining empires are identified readily with diminishing territorial size. In the Mesopotamian case, however, there are at least two problems with Taagapera's size index. One of the problems is that the Taagapera measurement begins quite late (only after 3000 вСЕ) while Mesopotamian analysts have pushed the origins of the Urukian phenomenon much farther back in the $4^{\text {th }}$ millennium BCE than had earlier been the case (see, especially, Rothman 200I). The scale and scope of the $4^{\text {th }}$ millennium activities is also now known to be greater than was thought possible in the late I970s. As a consequence, the Taagapera Mesopotamian series is dated. ${ }^{11}$ A second and more serious problem is seen quite clearly in figure 2 which plots an interpolated version of the Taagapera data. ${ }^{12}$ Since the index privileges the size of empire alone, any empirical analysis of this particular series reduces to explaining the Akkadian iteration of the centralization-fragmentation cycle. ${ }^{13}$ Other centralization iterations lack the area to compete for equal attention. That bias may be perfectly appropriate for some

11. I have not examined the other imperial series developed by Taagapera and, therefore, cannot comment on whether this is a general problem or one confined to Mesopotamia.

12. The interpolated data were obtained from a data file on extrapolated Taagapera imperial size information posted at Christopher Chase-Dunn's Urbanization and Empire Formation Project on the IROWS web page at http://irows.ucr.edu/

13. Interestingly, Algaze (1993: 2-3, 108) asserts that the $4^{\text {th }}$ millennium Urukian expansion encompassed more territory than the Akkadian empire in the $3^{\text {rd }}$ millennium. This argument which seems perfectly plausible raises the additional question of indirect versus direct control/influence. 
Figure 2 - Taagapera Imperial Size

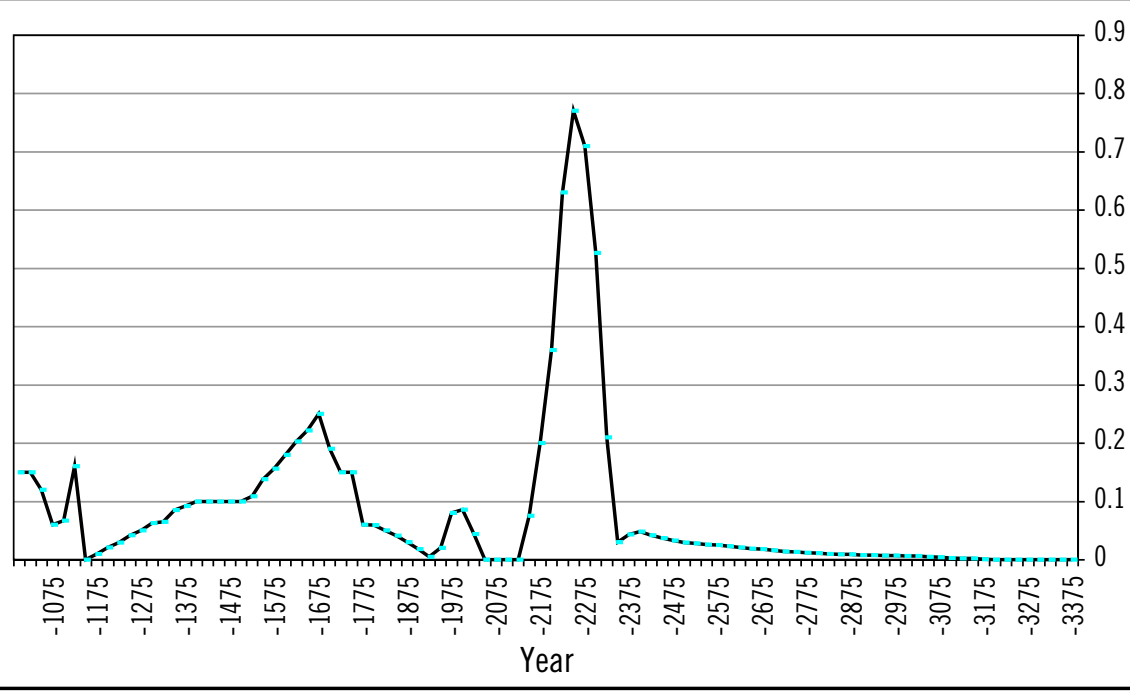

questions. ${ }^{14}$ If, however, the empirical challenge is to discriminate between periods of power concentration and deconcentration, any series that privileges one period of concentration over all others is undesirable. Nonetheless, we can retain the imperial size indicator for modeling purposes as long as we keep in mind its limitations.

Putting aside the overt attractions of an interval scaled size index, a nominal index distinguishing between periods of more centralization and less centralization should suffice. I accept Marcus' four candidates for periods of greater centralization (Uruk, Akkad, Ur III, and the Hammurabi effort) but add a fifth one for the Kassite empire of the second half of the and millennium. The dating for these five iterations is: Urukian (3800-3100), Akkad (2350-2150), Ur III (2100-2000), Hammurabi's Old Babylonian empire (1760-1600) and Kas-

14. See, for instance, the Chase-Dunn et al. (2002) study on the relationship between population density and military power. More generally, though, there is an additional problem if each successive iteration of centralization has more effective coercive and transportation resources at its disposal, one might anticipate an expanding capability to reach and control larger chunks of territory over time. Such a trend might interfere with the analysis of a series based on territorial size (a control that Chase-Dunn and associates do administer) emphasizing imperial bulk. Still, this is not a problem for ancient Mesopotamia, especially pre-Assyria. site (I415-II54). Periods of centralization are coded as I and periods of fragmentation are coded as $\mathrm{O}$.

\section{Population Growth}

Regrettably, there are no population censuses for ancient Mesopotamia. There are, however, at least two estimates that encompass the ancient era. One is developed by Whitmore et al. (1990) and is restricted to a small number of population sizes separated by a considerable number of years. These observations could be interpolated into a series, with the help of some heroic assumptions, if it were not for a rather peculiar feature of the observations. Their reconstruction suggests population expansion peaking around $2500 \mathrm{BCE}$, a period of contraction, and then a rather large increase around 1900 вСЕ that represents more than double the population size of $2300 .{ }^{15} \mathrm{I}$ am skeptical that this very large 1900 вСЕ surge is all that plausible in the absence of information on an incredibly massive Amorite influx and, therefore, am reluctant to rely on the estimated information.

A second compilation of selected population data is more promising. Modelski (2003) represents an effort to re-examine and improve upon Tertius Chandler's (1987) catalogue of city sizes. Modelski's project is especially useful for a Mesopotamian analysis because he emphasizes pushing back the estimation of city sizes to the $4^{\text {th }}$ millennium Urukian era and is also strongly interested in filling in gaps in Chandler's sketchy ancient world database. The outcome, for our purposes, is a century-by-century list of cities in Mesopotamia with populations estimated to be greater than I0,000-Modelski's threshold for cities in the ancient world. Aggregating the estimated population sizes, see Table I, gives us an estimate of the size of Mesopotamia's urbanized population that probably errs on the conservative side given the threshold size filter and our hazy information about the number of people residing in cities. Whether the numbers are close or close enough to the "real" numbers is not a question that we need be concerned with here. ${ }^{16}$ More important is whether the periods of population expansion and contraction depicted in this index, as plotted in Figure 3, seem reasonable.

15. They have Mesopotamian or, more technically, Tigris-Euphrates lowlands population at 360,000 in $2500,300,000$ in 2300 and 630,000 in I 900 .

16. Obviously, there are also limits to the extent to which one could push this question in any event. 
Table 1 - Mesopotamian Cities (with 10,000 population)

\begin{tabular}{|c|c|c|c|c|c|c|c|c|c|c|c|}
\hline Cities & 3700 & 3500 & 3300 & 3000 & 2800 & 2500 & 2400 & 2300 & 2200 & 2100 & 2000 \\
\hline Adab & & & & & 10 & 20 & 10 & 10 & 30 & 10 & 10 \\
\hline Akkad & & & & & & & & & 30 & & \\
\hline Akshak & & & & & & 10 & 20 & & & & \\
\hline \multicolumn{12}{|l|}{ Assur } \\
\hline \multicolumn{12}{|l|}{ Babylon } \\
\hline Badtibira & & & & & & & & & & & \\
\hline Eridu & $6-10$ & 10 & 10 & 10 & & & & & & & \\
\hline \multicolumn{12}{|l|}{ Eshunna } \\
\hline Girsu & & & & & & & 40 & 80 & 50 & 80 & 40 \\
\hline Isin & & & & & & & & & & & 40 \\
\hline Kesh & & & & & 40 & 10 & 10 & 10 & & & \\
\hline Kish & & & & & 30 & 20 & & & & & \\
\hline Lagash & & & & & & 60 & 30 & & & & \\
\hline Larak & & 10 & 10 & 10 & & & & & & & \\
\hline Larsa & & & & & 16 & 10 & & & & & 40 \\
\hline \multicolumn{12}{|l|}{ Masham-sha } \\
\hline Nagar & & & & 20 & & & & & & & \\
\hline Nina & & & & & & & & & & 10 & 10 \\
\hline \multicolumn{12}{|l|}{ Nineveh } \\
\hline Nippur & & & & 10 & 10 & 20 & 20 & 30 & 30 & 30 & 30 \\
\hline Shuruppak & & & & & 30 & 30 & 10 & & & & \\
\hline \multicolumn{12}{|l|}{ Sippar } \\
\hline Suheri & & & & 10 & 10 & 10 & 10 & & 10 & 10 & 10 \\
\hline Umma & & & & & 20 & 40 & 40 & 40 & 10 & 20 & 25 \\
\hline Ur & & & & & 12 & 10 & 10 & 20 & 40 & 100 & 20 \\
\hline Uruk & & 14 & 40 & 40 & 80 & 40 & 30 & 30 & & 30 & 30 \\
\hline Zabalam & & & & & 10 & 10 & 10 & 10 & 10 & 10 & 10 \\
\hline Total & 8 & 34 & 60 & 100 & 268 & 290 & 240 & 230 & 210 & 300 & 265 \\
\hline
\end{tabular}

The urban population estimate shown in Figure 3 suggests southern Mesopotamian population expanded through the first half of the $3^{\text {rd }}$ millennium. Urban population growth faltered prior to the Akkadian era and did not turn around, albeit briefly, until the Ur III period. After the end of the $3^{\text {rd }}$ millennium, urban population growth plunged for half a millennium before rebounding to a limited extent around a Babylonian-centered resurgence for a few centuries toward the end of the and millennium. Thus, utilizing Modelski's (2003) ancient Mesopotamian city population data yields, basically and very roughly, an inverted " $U$ " pattern from the $4^{\text {th }}$ millennium to the mid-2nd millennium, with a significant dent in the pattern in the 2 nd half of the $3^{\text {rd }}$ millennium. The long ramp upwards to $2500 \mathrm{BCE}$ is probably suspiciously uniform or too smooth but the strong growth in the late $4^{\text {th }}$ and early $3^{\text {rd }}$ millennia as well as the problems manifested in the second half of the $3^{\text {rd }}$ and first half of the 2 nd millennia certainly appear to correspond with our understanding of Mesopotamian his-

\section{Table 1 (cont) - Mesopotamian Cities (with 10,000 population)}

\begin{tabular}{|c|c|c|c|c|c|c|c|c|c|c|}
\hline & 1900 & 1800 & 1700 & 1600 & 1500 & 1400 & 1300 & 1200 & 1100 & 1000 \\
\hline $\begin{array}{l}\text { Adab } \\
\text { Akkad } \\
\text { Akshak }\end{array}$ & 10 & 10 & & & & & & & & \\
\hline Assur & 10 & 15 & 10 & 10 & 10 & 10 & 15 & 20 & 12 & 12 \\
\hline $\begin{array}{l}\text { Babylon } \\
\text { Badtibira } \\
\text { Eridu }\end{array}$ & & 10 & 60 & 60 & & $10+$ & $10+$ & 75 & 75 & 100 \\
\hline $\begin{array}{l}\text { Eshunna } \\
\text { Girsu } \\
\text { Isin } \\
\text { Kesh } \\
\text { Kish }\end{array}$ & $\begin{array}{l}10+ \\
40\end{array}$ & 20 & & & & & & 40 & & \\
\hline $\begin{array}{l}\text { Lagash } \\
\text { Larak } \\
\text { Larsa } \\
\text { Masham-sha }\end{array}$ & $\begin{array}{l}40 \\
10\end{array}$ & $\begin{array}{l}40 \\
15\end{array}$ & & & & & & & & \\
\hline $\begin{array}{l}\text { Nagar } \\
\text { Nina } \\
\text { Nineveh } \\
\text { Nippur }\end{array}$ & $\begin{array}{l}10 \\
20\end{array}$ & 20 & & 10 & 10 & $\begin{array}{l}10 \\
20\end{array}$ & $\begin{array}{l}10 \\
30\end{array}$ & $\begin{array}{l}10 \\
20\end{array}$ & 10 & 10 \\
\hline $\begin{array}{l}\text { Shurrupak } \\
\text { Sipar } \\
\text { Suheri } \\
\text { Umma }\end{array}$ & & 40 & & & & & & & & \\
\hline $\begin{array}{l}\text { Ur } \\
\text { Uruk } \\
\text { Zabalam }\end{array}$ & $\begin{array}{l}10 \\
30 \\
10\end{array}$ & 10 & & & & 30 & 30 & & & \\
\hline Total & 200 & 190 & 70 & 80 & 20 & 80 & 95 & 165 & 97 & 122 \\
\hline
\end{tabular}

Source: Modelski (1993)

\section{Figure 3 - Estimated Urban Population}

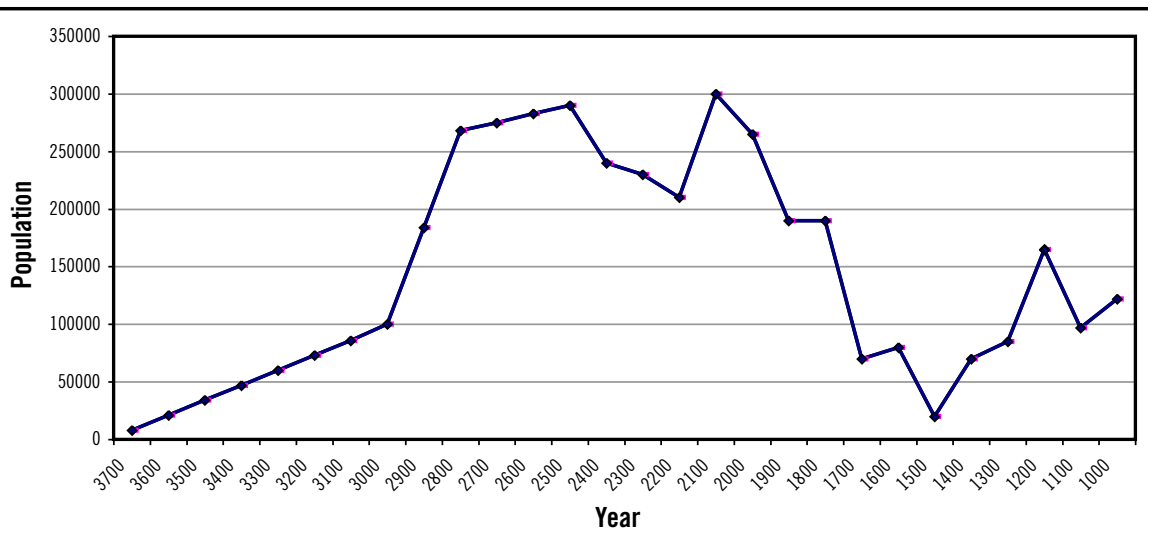


tory. The degree of correspondence appears to be adequate to justify moving forward with the use of this indicator.

The main liability of this indicator, of course, is that we are assuming that population growth is correlated with city growth. If city size waxes and wanes without any relationship to overall population growth, the assumption would be unwarranted. If the assumption is unwarranted, fluctuations in city size are not irrelevant. They would still reflect a form of breakdown in complexity as people fled cities for the rural countryside, or were encouraged by governmental policies to work on rural estates. Fluctuations in urban population would then become an alternative measure of fragmentation. ${ }^{17}$ However, McEvedy and Jones (1978: 149) argue for a boom and bust cycle in Sumerian population growth dependent largely on variable salinity problems. They suggest that population increased from I0,000 to 100,000 in the $7^{\text {th }}$ to $5^{\text {th }}$ millennia, with an increase to 500,000 in the middle $3^{\text {rd }}$ millennium before the over-irrigation and agrarian productivity problems set in towards the end of the $3^{\text {rd }}$ millennium. They note that barren fields were abandoned but also that population size probably declined by roughly 25 percent (to $.75-\mathrm{I}$ million). As the fields became more fertile in the and millennium, they think population increased by a third (to I-I.25 million) before dropping again later in the same millennium, only to increase again at about the same rate as before and for the same reasons toward the end of the 2nd millennium. ${ }^{18}$ None of these numbers are carved in stone, figuratively or otherwise, but they do seem to support using an indirect urban population measure that also reflects boom and bust dynamics. ${ }^{19} \mathrm{We}$

17. Moreover, cities loom large in the development of Mesopotamia. Adams (I988: 36-7) observes that "in Mesopotamia, cities are the primary units in terms of which it is possible to identify civilizational growth and decline... insofar as we can apprehend Mesopotamian civilization, it is inseparable from groups and institutions that flourished only as cities flourished."

18. McEvedy and Jones (I978: I49) also argue that this boom and bust cycle persisted into the $\mathrm{I}^{\text {st }}$ millennium BCE. Population is thought to have nearly doubled thanks to the Assyrian centralization by the $7^{\text {th }}$ century. With the collapse of the Assyrian empire, population size declined to $2^{\text {nd }}$ millennium levels or lower and did not expand much again until the Abbasid expansion a millennium later.

19. Wright (200I:I45) suggests that there were discernible fluctuations in population as early as the $5^{\text {th }}-4^{\text {th }}$ millennia. He believes overall population probably declined in $4 \mathrm{I} 50-3800 \mathrm{BCE}$ interval, grew in the $3800-3350 \mathrm{BCE}$ period, and regards the 3350-3 100 BCE years as unclear in regards to population growth. These fluctuations are not manifested in the city data that I am relying upon but then the first two periods are also prior to the onset of the empirical analysis. will employ both the aggregate size of urban population and the rate of urban population growth in our subsequent modeling.

\section{Economic Fluctuations:}

Frank and Thompson (forthcoming) have characterized each century between 4000 and 1000 BCE as predominately prosperous or depressed. These categorizations are based on an extensive survey of the appropriate historical and archaeological discussions relating to 15 zones within Afro-Eurasia. ${ }^{20}$ Only direct references to the state of the economy were utilized in order to make the coding as conservative as possible. Not every century could be coded. Some centuries, mainly in the fourth millennia, have little relevant coverage. A few centuries were coded as uncertain (sources disagreed) or mixed (economic fortunes varied temporally within a century or within the zone being coded).

Table 2 summarizes the information applicable to the Mesopotamian Bronze Age. The Mesopotamian economic fluctuations tend to cluster with prosperous centuries becoming less common over time. Relatively prosperous centuries characterized the $3800-3300$ and possibly the $2700-2300$ periods. Only two economically prosperous centuries are indicated after 2300. Periods of contraction occurred in 4000-3800, 3200-2900, 2300-2100, 2000-1900, $\mathrm{I} 600-1400$, and $1200-1000$, although one might extend some of the contraction periods if the "mixed" centuries are treated as limited growth years. Centuries of economic contraction are coded as I and other centuries are coded as $\mathrm{O}$.

\section{Trade Collapse}

Thompson (2001a, 200Ib, forthcoming-b) has surveyed the emergence of southwest Asian trading networks from about the eighth millennium ВСE. to the end of the Bronze Age. Down-the-line trading interactions, centered on the movement of stones for tools and jewelry and stretching as far east as Afghanistan, gave way in the fifth and fourth millennia to increasingly Mesopotamian-centered resource acquisition networks (Halaf, 'Ubaid, and Uruk). In the $4^{\text {th }}$ millennium, the Sumerian-centric network, involving a mixture of traders, trade enclaves, and colonial settlements, reached to Anatolia and Iran in the north, Syria in the west, and Egypt in the south. Towards the end of

20. This approach to measurement is obviously quite crude and is justified in an effort to encompass all of Afro-eurasia for fairly long periods of time. Some of the justification is lost in applying the Mesopotamian coding to an analysis less ambitious in scope. Yet alternative and more accurate indices, while certainly conceivable, do not yet exist. 
Table 2 - Mesopotamian Economic Fluctuations

\begin{tabular}{clcl}
\hline Year & $\begin{array}{l}\text { Economic } \\
\text { Flucuation }\end{array}$ & Year & Economic \\
\hline $4000-3900$ & contracting & $2500-2400$ & Expanding \\
$3900-3800$ & contracting & $2400-2300$ & Expanding \\
$3800-3700$ & expanding & $2300-2200$ & Contracting \\
$3700-3600$ & expanding & $2200-2100$ & Contracting \\
$3600-3500$ & expanding & $2100-2000$ & Expanding \\
$3500-3400$ & expanding & $2000-1900$ & Contracting \\
$3400-3300$ & expanding & $1900-1800$ & Mixed \\
$3300-3200$ & mixed & $1800-1700$ & Mixed \\
$3200-3100$ & contracting & $1700-1600$ & no data \\
$3100-3000$ & contracting & $1600-1500$ & Contracting \\
$3000-2900$ & contracting & $1500-1400$ & Contracting \\
$2900-2800$ & no data & $1400-1300$ & Mixed \\
$2800-2700$ & no data & $1300-1200$ & Expanding \\
$2700-2600$ & expanding? & $1200-1100$ & Contracting \\
$2600-2500$ & expanding? & $1100-1000$ & Contracting \\
\hline
\end{tabular}

Source: Extracted from Frank and Thompson (2002)

the fourth millennium, the Sumerians were forced to retrench, due probably to some combination of internal and external turmoil related to the expansion of Trans-Caucasian groups and the rise of Elam. The Mesopotamian links to the north were taken over by intermediaries; the Egyptian link was severed for a time. Sumerian cities gradually were increasingly reoriented towards trade coming through the Gulf, via Dilmun, from Oman and Indus.

Towards the end of the 2nd millennium a variety of problems-Mesopotamian militarism, declining agrarian productivity, the decline of Indusprompted a gradual shift toward the eastern Mediterranean as a focal point of southwest Asian trade. Aegean traders, Egyptian wealth, and Syrian-Levantine trading cities created a new system stretching west to Greece, Italy, and beyond in drawing in European resources to feed eastern Mediterranean demands. The reorientation toward the west was accelerated by the full collapse of Indus by the $\mathrm{I}^{8^{\text {th }}}$ century and, ironically, by the Hyksos incursions into Egypt about the same time. The Hyksos domination of parts of Egypt further cemented Egypt's trade connections with the Syrian-Levantine coast and immediate inte- rior. Increasing in volume and geographic scope into the 1300 , the entire system collapsed around I200. A number of eastern cities and empires were destroyed. Migrations of people into Greece and around the eastern Mediterranean littoral were set into motion, reaching as far as Egypt and its battles with intruding "Sea Peoples" and Libyans. With the exception of some activity on the part of Phoenician cities, a two century dark age ensued in which trading interactions were severely restricted.

Thus, there were three evident periods of trade crisis, reorientation, or collapse in the ancient world: circa roughly $3200-3000,2200-2000$, and $1200-$ 1000 (and beyond). ${ }^{21}$ The maximal period of collapse came only toward the end of the and millennium, with reorientation even further to the west and then back to the east much later in the first millennium все. The earlier two crises, $3200-3000$ and 2200-2000, stopped short of attaining the post-I200 dark age. The emphasis was more on gradually finding replacements for imports and exports that had become difficult to sustain. Periods of trade collapse are coded as I and other periods are coded as o.

\section{Regime Transitions}

If the historical sequence of ancient regimes in Mesopotamia is characterized by a fair amount of consensus, there are differences of opinion about the precise number of years to assign to each period. Yet the differences do not seem so great that any obvious validity threats are posed by adopting one chronology over another. More threatening perhaps is the tendency to revise the chronological schedules every so many years as new information comes to light. Baines and Yoffee (1998: 202) advance the following schedule: Ubaid (5000-4000), Uruk (4000-3100), Jemdet Nasr (3100-2900), Early Dynastic (2900-2300), Akkad (2350-2150), Third Dynasty of Ur III (2100-2000), Old Babylonian (2000-1600), and Kassite (1590s-1150). It is based on fairly recent periodization principles, circa the mid-I99os, but it is still not quite the last or even the latest word on the subject. Algaze et al. (1998) and Joffe (2000) discuss some of the implications of the most recent revisions in the Mesopotamian schedule which are not fully reflected in the Baines and Yoffee schedule. Essentially, these revisions have the effect of extending the Uruk phase even farther back in time and, as such, address an earlier period than the one that will receive most of the attention in this analysis. Prehistorical dating, no doubt, will continue

21. These dates are meant to be generic to the ancient world (Afghanistan to Egypt) and, therefore, do not match Mesopotamian realities precisely. 
to be debated precisely because it is about prehistorical periods of time and the temporal evidence is often based on indirect measurements. Dating regime transitions in the third and second millennium $\mathrm{BCE}$, the period about which the hypotheses are most oriented, tend to be more stable. The only modification made to the Baines-Yoffee schedule is that the Kassite period is altered to begin around 1415 as opposed to the 1590 os. Periods in which regime transition took place are coded as I. All other periods are coded as $O$.

Is "regime" the right word for these chronological markers? Perhaps not given all the connotations associated with the regime concept. I employ it here in the context suggested by Spier (1996: I4) as "a more or less regular but ultimately unstable pattern that has a certain temporal permanence." In short, these are sets of recognizable patterns that give way to other recognizable pattern packages and can be applied to multiple types of human activity. ${ }^{22}$

\section{Center-Hinterland Conflict}

Data on incursions/migrations are intended to capture some sense of the timing of conflict between centers and their hinterlands. In the ancient world system, there is little likelihood of capturing this rhythm with any great precision but it should be possible to develop a sense for its basic beat. By combing references in the historical literature to center-hinterland clashes and movements of peoples, the idea is to systematize as best as possible what we know at this time, subject to the inherent limitations of the subject matter.

Most typical of the literature are fairly vague references to some ruler fighting hill or desert tribes early or late in his reign. Which hill tribes are not always noted. Exactly where they clashed or who initiated the encounter is frequently absent. What size the fighting forces might have been is almost never noted (or known). What they are fighting about is simply a question that only rarely surfaces. Consistent with these approaches to the subject matter is what might be called a professional bipolarity. Most historians are not too interested in the clashes between hinterland and centers. Granted, the information that is available is quite poor and thus there is very good reason for professional caution. But, it also seems fair to say that most historians treat hinterland peoples much like their favorite subjects did-that is as intermittent nuisances of the general landscape-or they casually bestow great causal agency on hinterland depre-

22. Climate and rivers can be described in regime terms as well. Note that the overlap between centralization/fragmentation and regime transition suggests that the two measures should not be employed in the same equations. dations as significant factors in the downfall of various centers without really pondering too much about the implications.

An enumeration of ancient southwest Asian center-hinterland conflict (Thompson 2002) lists little known activity prior to the end of the fourth millennium. An important evolutionary development helps explain this slow-toemerge phenomenon. The people who became sedentary, city dwellers initially were not particularly sedentary. The impression one has is that all groups were initially mobile, moving from camp-site to camp-site, subject to natural catastrophes and the exhaustion of local food sources. Cities or concentrations of sedentary people emerged gradually in some places and perhaps abruptly in others. More clearly gradual was the emerging division of labor between sedentary farmers and city-dwellers and non-sedentary herders. Only after these societal dualities emerged was it possible for hinterland-center conflict to emerge fully in the late fourth and third millennia. ${ }^{23}$

Focusing on the Mesopotamian experience, the initial period of significant conflict was related to the ambiguous movement of tribal groups from Georgia toward the Mediterranean and the in-migration of Semitic-speaking tribes from the Syrian and Arabian deserts. However, the tribal influx may have been so

23. Scholars do not fully agree on the timing of the emergence of a division of labor between sedentary and non-sedentary economic activities. For instance, Sherratt (I996)

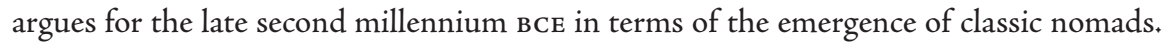
But it is clear that he had horse-riding, steppe warriors in mind and that this conjuncture required the coming together of European and Mongolian peoples in Central Eurasia and the full domestication of horses. Hole (1994) stresses that the bifurcation in economic strategies was roughly simultaneous with the first emergence of cites, which would place it in the fourth millennium все. But even if the division of labor emerged early, it is quite likely that some time was needed for the emergence of meaningful center-hinterland conflict. If nothing else, the development of a strong hinterland military mobility capability awaited the domestication of horses and camels (Butzer 1997: 266). One would also expect that the initial contacts would come in the form of center attempts to either protect vulnerable trade routes and/or acquire resources needed for urban life. Based on the better known East Asian case, raiding and trading should also have preceded any hinterland attempts to take over the center. In Mesopotamia, hinterland infiltration of the center over hundreds of years also preceded any takeover attempts. Moreover, the center forces initially should have had some capability advantages over hinterland tribes that gradually eroded as the highland and desert tribes learned how to cope with center forces, especially when those center forces grew weaker. It was only later (early-to-midsecond millennium) that hinterland forces emerged with superior weaponry in the form of chariots and compound bows. 
gradual that the Sumerians were able to absorb, manage, and probably assimilate the immigrants without a great deal of ethnic strife. Eventually, some of the former immigrants took over Sumer about midway through the $24^{\text {th }}$ century, but this was more an internal realignment of elite/ethnic structures as opposed to an external conquest.

Subsequent incursions tended to cluster in some years more than in others. The Akkadians overthrew the Sumerians from within Mesopotamia around 2350 BCE Beginning around 2200, Gutians and Lullubi were causing increasing problems in the east. In the west, Su, Hurrians, and Amorites in general were in motion, attempting to move into Mesopotamia. From about 2000-1750, there was still activity but it seems much less than the amount that was associated with the 2200-2000 period. The pace picked up again in the early 1700 s with various hinterland groups in the east and the west on the attack. Few entries are recorded for Mesopotamia in the 1600 s but that suggests more center disintegration than hinterland quiescence. At some point after the 1590 s, Kassites took over Babylon, apparently by default, in the aftermath of an Hittite assault on that city. ${ }^{24}$ Some urban Assyrian resurgence was demonstrated in the 1300 s and early 1200 s but towards the end of the period of primary interest, the I2th century ВСE and later, Mesopotamia was characterized by a large-scale in-migration of Aramaeans from the western deserts.

The incursions/migrations data, unfortunately, do not lend themselves readily to treatments as time series. ${ }^{25}$ It is better to regard them as approximations of fluctuations in center-hinterland conflict. The most major periods of conflict can be reduced by interpretation to the following short list. In the Mesopotamian case, it was first the movement of Trans-Caucasians and Amorites towards the end of the fourth millennium, followed by Gutian attacks in the 2100s, and then the Amorite attacks in the 2000s which led to a number of Amorite dynasties and rulers in the Old Babylonian period. The Kassite takeover in the I50os in the wake of an Hittite attack on Babylon was the next major hinterland blow to the ascendancy of a center, and many consider it a terminal blow to Mesopotamian centralization prospects. Nonetheless, another discernible Mesopotamian round of hinterland incursions began with the increase of

24. Even the dating of the takeover of Babylon remains subject to debate (see Gasche et al.1998).

25. They also ignore a couple of millennia of Elamite conflict with people residing in Lower Mesopotamia because it is difficult to view the Elamites as hinterland groups even if they were sometimes allied with hinterland forces in their Mesopotamian attacks.
Aramaean pressures towards the end of the second millennium. The following Mesopotamian center-hinterland conflict clusters (3200-3000, 2200-2000, $1600-1500$, and $1200-1000$ ) are viewed in this analysis as centuries of especially significant hostility. These periods are coded as I while other periods are coded as 0 .

Since there is some considerable overlap in the three indicators of politicaleconomic crisis (hinterland incursions, trade collapse, and regime transition), it will prove useful at a later point to amalgamate the three indicators into a summary crisis index. This is done by awarding 25 points for the presence of each one of the three types of problem. The amalgamated index thus varies between a low of $o$ and a high of 75 .

\section{Climate}

Systematic records were not kept on weather and river levels in ancient times. Dark ages are especially problematic for historians because few written records survive. Yet these Dark Ages recur and it is difficult to escape the feeling that the dark ages were instrumental, if not crucial, to bringing about longterm changes in the areas in which they take place. There are also fairly strong clues that these intervals are often preceded by drought, famine, and migrations induced by climate changes ${ }^{26}$ But while we may have evidence of the drought, famine, and migrations, the evidence on climate change is often weak.

Still, the traditional opinion has been that there had been little change in Near Eastern climate over the last Io,000 years. If that was the case, why even bother exploring climate as an explanatory factor? Thus, the study of climate is plagued at the outset by a combination of bad data and limited professional incentive. Another problem is the prevailing ambivalence as to whether to stress climate effects or human reactions to climate change. If too much emphasis is placed on the climate effects, the explanation easily begins to sound deterministic. The weather changed. People died from a lack of water or moved elsewhere. But we know that not everyone died and not everyone moved. Obviously, different strategies were employed to cope with environmental changes, if that is what occurred. We also know or suspect that other things besides climate change (e.g., corruption, internal and external violence, governmental entropy, collapsing trade, declining productivity) were ongoing. Are all of these processes also effects of climate? Should they share explanatory credit? Or is it possible that climate changes are spurious factors and the long-term changes we observe are

26. See, for instance, Chew (I999, 200I). 
due to "on-the-ground" processes related exclusively to complex human interactions? The prudent way out is to simply skip the subject altogether.

At the same time, though, the recurrence and probable significance of dark ages is difficult to evade. We also have increasing reason to suspect the generalization that southwest Asian climate has not changed in the past Io,ooo years. Moreover, in studying the recurring phenomena of dark ages in the long-term, it is nigh impossible to avoid the likelihood of some substantial connection to the onset of climate problems. Sometimes, the prudent way out is not always palatable.

It should also be recognized that there are dissenting views on climate among scholars of the ancient Near East. Bell (197I, 1975) had earlier drawn attention to the importance of Nile fluctuations and its implications. She also suggested that these periodic interactions with deteriorating environments should be anticipated in other parts of the ancient world, not merely Egypt. Weiss (Weiss and Courty 1993; Weiss et al. 1993) has stressed environmental change as critical to the turmoil of the 2200-2000 era. Elsewhere (Weiss 2000: 77), he has also suggested that climate changes might have been responsible for problems at the end of the $5^{\text {th }}$ (the "Ubaid-Uruk transition) and the $4^{\text {th }}$ millennium Uruk urbanization and its trading network retrenchment). ${ }^{27}$ Butzer (1995: 138) goes one step further by drawing attention to what he calls "firstorder anomalies" of general atmospheric circulation. Three pan-Near Eastern "dry shifts" are identified as having occurred around 3000, 2200, and I300 вСЕ. Protracted periods of low Mesopotamian rainfall, as registered in Lakes Van and Zeribar sediment layers and pollen traces, occurred around 3200-2900, $2350-2000$, and $1300-1200 .^{28}$

While Butzer (1995) did not pursue the political-economic implications of the first-order anomalies, Matthews (2003: I0O-OI) criticizes an analysis of

27. Interestingly, Weiss (2000: 84) stresses what he calls the incursions of southerners (Sumerian and Akkadian imperialism) into north Mesopotamia as a response to ecological problems. This emphasis reverses the focus in this paper on hinterland incursions against the center, but is consonant with the examination of governmental regime transitions. At the same time, Weiss (2000: 88-89) acknowledges increased pastoralism and nomadic incursions against sedentary areas in periods of aridification.

28. These "anomalies" suggest causation at a level greater than the local or even regional weather systems. Whereas Egypt and Indus shared an African monsoonal common denominator (Weiss 2000), Mesopotamian river levels are predicated on Anatolian precipitation. Therefore, similar climate problems in Mesopotamia and Egypt at roughly the same time, especially in conjunction with similar problems outside southwest Asia, suggest world-level climate change was at work. cycles of political consolidation and fragmentation (Marcus 1998) for ignoring the "central role of climate and environment" in bringing about the breakdown of Mesopotamian states toward the end of the fourth, third, and second millennia. Unfortunately, Matthews stops short of pursuing this issue beyond advancing the criticism. ${ }^{29}$ Bell, Weiss, Butzer, and Matthews are most suggestive and encouraging but all stop short of fully developing systematic linkages to the political-economic consequences of environmental deterioration.

In a generally arid area, the first weather dimension that comes to mind is rainfall. One problem with generalizing about precipitation levels in the Middle East is that rainfall for the entire region may be averaged for any given time period but different areas will still be affected differently. If one area averages Ioo millimeters a year and another 500 millimeters and they both experience Ioo millimeters less in a dry year, the first area will become unlivable while the second one may experience some mild drought. There are varying precipitation zones in southwest Asia (for instance, precipitation currently tends to increase as one moves away from Arabia in a northeasterly direction-see Nissen 1988: 59).

Temperature fluctuation is a second obvious dimension of weather. On this score, there does not appear to be a great deal of information. We have some limited information on relatively short periods of time (e.g., less than a millennium).$^{30}$ However, the most useful array of information is provided by Fairbridge et al. (1997). Based on an analysis of geological information, they are able to generate a table of cool and warm/wet and dry alterations that characterized southwest Asia, albeit subject to various qualifications from period to period by sub-region. Converting this information to our focus on centuries, ancient southwest Asian periods of dry and warm climate were: 3250-2900, $2700-2345,2200-1650$ (described as a period of widespread dessication), 1650I400 (the dessication continued but not as badly as in the immediately preced-

29. Butzer (I995) is cited as the source for the timing of "episodes of climatic adversity and aridification." However Matthews curiously places the second millennium episode in I400, as opposed to Butzer's I300-I200 identification. Marcus, for her part, has responded (in a personal communication with the author) that she did consider climate as an explanatory variable and decided not to pursue it.

30. Sources on ancient southwest Asian climate include Diester-Haass (I973), Butzer (1976, I995), Oates and Oates (1977), Van Ziest and Bottema (1977), Erinc (1978), Neumann and Sigrist (1978), Schoell (1978), Van Ziest and Woldring (1978), Hoffmann (I979), Kay and Johnson (I98I), Nissen (I988), Fairservis (I992), Bottema (1997), Fairbridge et al. (I997), Lemcke and Sturm (1997), Potts (I997), Kerr (1998), and Weiss (2000). 
Figure 4 - Tigris-Euprates River Levels

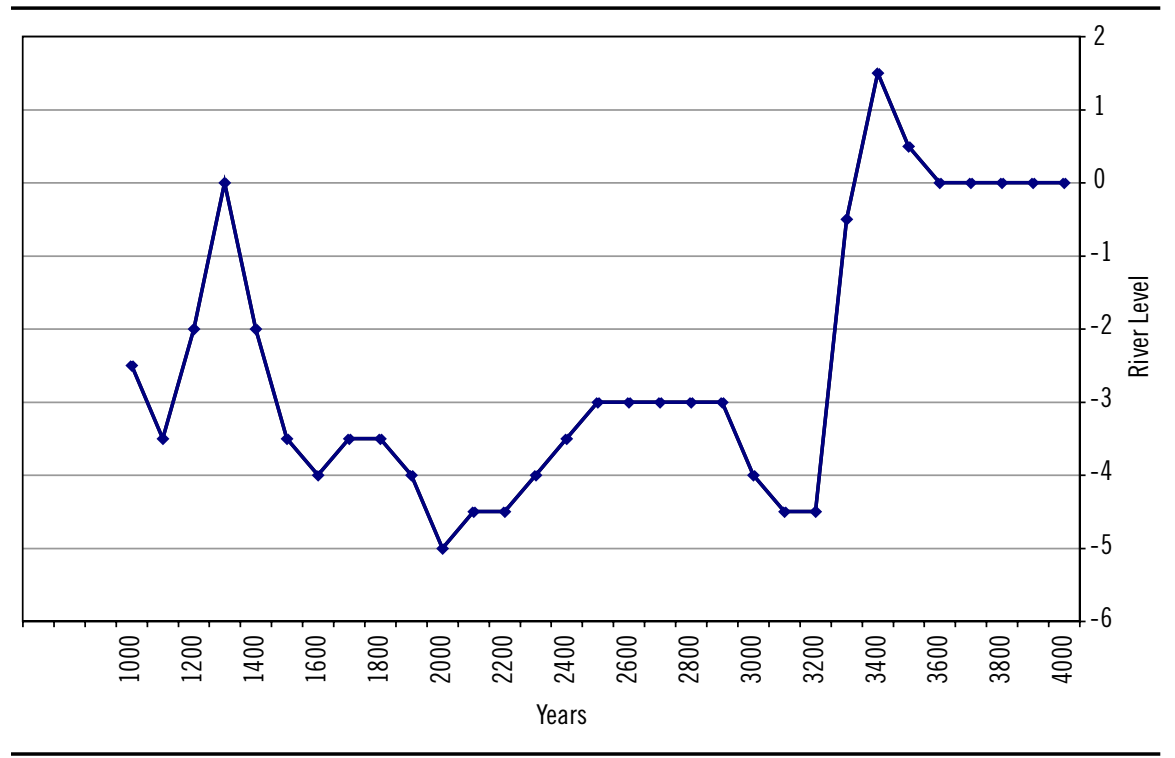

ing period), or 2200-I400, and I200-I000. I code years of warm/dry as I and other years as o to create one index of rising temperatures. But one could argue that such a coding fails to differentiate between extended periods of warmth and drying as opposed to the initial onset or more brief onsets of increased temperatures. To check this possibility, a second index of warming/drying is created in which each subsequent interval in a sequence of warming/drying is given a higher score. For instance, the first interval is coded as I, the next adjacent interval as 2 and so on, with the idea being that sustained warming/drying should have a greater behavioral impact than relatively brief onsets.

One might also wish more information on climate such as wind forces and directions or even dew levels which can make some difference in dry-zone agriculture, but it is doubtful that too much more detailed information is likely to be forthcoming. One exception, and it is one that will prove to be a rather major one, is river level data. Both Mesopotamia and Egypt were constructed around river systems and much of their agrarian success and transportation opportunities were governed by the volume of water flowing through the Tigris/Euphrates and Nile rivers. As it happens, we have some reconstructed information on river volume that is easier to interpret than the comparable information on temperature and precipitation. ${ }^{31}$

Figure 4 plots the reconstructed information we have on the Tigris/Euphrates river levels. The pattern is one of precipitous declines in the level from 3500 to $2900 \mathrm{BC}, 2500$ to $2000 \mathrm{BCE}$, and 1300 to IIOO BCE. In between these phases of declining water levels are periods of increasing water level although they never return to the levels of $4000 \mathrm{BC}$ until early in the first millennium. As in Thompson (forthcoming-a), an interaction index, combining periods of declining river levels and warming/drying (coded I when declining river levels coincide with warm/dry periods and o at other times), is also examined.

The data that are available do not lend themselves to being measured very well on an annual or even decennial basis. Twenty-five year intervals or four measurements per century are about as precise a measurement as can be expected. Given the slow-to-emerge urbanization phenomena in Mesopotamia, it seems unwarranted to initiate any analysis prior to $3400 \mathrm{BCE}$. The IO०O BCE termination date used in Thompson (forthcoming-a) is retained in acknowledgment of the customary distinction between the Bronze and Iron Ages in the Mediterranean-focused ancient world. Since the data represent a mixture of nominal and interval indicators, logit regression offers some gain over the earlier reliance on cross-tabulations.

\section{ANALYTICAL EXPECTATIONS}

In all, we have 2 indicators addressing 4 blocs of variables. Four (economic contraction, hinterland incursions, trade collapse, and regime transition) have been examined previously. They were found to be variably inter-related and linked significantly to the interaction effect of climate deterioration and river levels. The earlier analysis, however, was quite crude. Data were measured in

31. The source for the river level data is Butzer (I995: I33) who refers to his series as "inferred" volume flows but, unfortunately, does not discuss his specific approach to inference. In a personal communication with the author, Professor Butzer has acknowledged basing his river level estimates on Lake Van sediment data that he now considers somewhat less reliable than he had thought in the mid-I99os. Other analyses of reconstructed Tigris-Euphrates data are reported in Kay and Johnson (I98I) and Bowden et al. (I98I). Obviously, the data are not as hard as we might all prefer, but it is unlikely that superior alternatives for river level estimations will soon be forthcoming. A related question is whether it might be possible to push the time frame back even further. Hole's (I994; see also Stein I999) comment that an 'Ubaid peak was attained in 5200 BCE, followed by decline, the abandonment of some parts of Mesopotamia by $4800 \mathrm{BCE}$, and an increased interest in religion suggests that the Tigris-Euphrates water levels may have been influencing behavior even farther back in time. See Algaze (200I; and also Charvat 2002: 8) for an argument that the attributes of the southern Mesopotamian ecological niche enabled that area to be the first to take the lead in developing "complex civilization." 
century units of time (4000-Iо0о вСE). Data on Mesopotamia and Egypt were cross-tabulated together. The empirical focus was restricted to the inter-relationships between the one climate problem indicator and the four measures of political-economic crisis. The current analysis affords an opportunity to narrow the temporal unit of analysis, isolate Mesopotamian behavior, and substitute regression for cross-tabulations in an effort to assess the extent of inter-relationship among all of the variables. Yet since there is no reason that somewhat improved precision will lead to different findings, one minimal expectation is that the new analysis will reinforce the findings developed in Thompson (forthcoming-a). That is, political-economic crises should be expected to be interrelated and linked systematically to climate problems.

Precisely how the measures of climate and political-economic stress should be linked to the two proxy measures of diminishing marginal returns (the size and growth rate of the urbanized population) and two measures of centralization/fragmentation is less clear. One possibility is that the indicators of stress will be closely related to the urbanization and fragmentation measures. Stress and decline could go hand in hand even though it would seem unlikely that all 7 measures of stress (combining the climate, river level, and political-economic crises) would be equally linked to decline and entropy. From Tainter's perspective, for instance, the stress measures should be substitutable with climate deterioration causing problems in one instance and hinterland incursions in another. There is no theoretical expectation linked to the diminishing marginal return argument to assume that all types of stresses occur simultaneously and in each and every iteration. ${ }^{32}$ Consequently, it is also conceivable that the relationships between crisis/stress and population/fragmentation will prove to be less than systematic or statistically significant. In the "worst" case scenario, there will be no cross-bloc relationship at all. More likely, the outcome will resemble something in between the strong linkage of all II indicators and the absence of any linkage between the stress indicators and the population/fragmentation indicators.

At the very least, however, Tainter's argument does lead to an expectation that there should be a systematic or significant relationship between diminishing marginal return and centralization/fragmentation. Assuming the population proxies tap into the issue of diminishing marginal return, we should expect to find these minimal linkages.

32. The expectation that the crises come in clusters stems from a different theory, developed in Thompson (2002) that argues for 4 periodic systemic crises in ancient southwest Asia roughly at the end of the $4^{\text {th }}, 3^{\text {rd }}, 2^{\text {nd }}$ millennia , as well as in the middle of the $2^{\text {nd }}$ millennium всE.

\section{DATA ANALYSIS}

Table 3 summarizes the statistically significant bivariate relationships among the II indicators. In general, the two minimal expectations have been satisfied by the statistical outcome. The centralization/fragmentation measure is negatively related to the urban population measure. The $7 \mathrm{stress} / \mathrm{crisis}$ indicators are closely intertwined. Economic contractions are related positively to hinterland incursions and trade collapses. Regime transitions, trade collapses, and hinterland incursions are all positively related to one another. Each of the four political-economic crises is related to Tigris-Euphrates river levels, increasingly warm temperatures, and/or the interaction of the two climate deterioration indicators. Centralization is positively related to conducive Tigris-Euphrates river levels.

Two of the statistically significant findings link the interval-scaled approach to warming/drying index (successive intervals of warming/drying receive increasingly higher scores - rising temperature [b] in table 3) with urban population growth rate and trade collapse. The link to urban population growth rate is negative and certainly plausible. It took successive intervals of warming/drying to influence urban population. Less clear cut is the negative linkage of successive intervals of warming to trade collapse. This finding should not be read as suggesting that trade expanded as the climate became increasingly warm. Rather, it suggests that trade collapses tended to occur early, as opposed to later, in extended warming sequences. Again, though, the most useful finding, and certainly the most plausible one, is the positive link between trade collapses and the interaction of falling river levels and warming/drying.

Less easily anticipated were the linkages between the political-economic/ climate blocs of indicators and the indicators of urban population and fragmentation. The observed outcome definitely falls in between the endpoints of very strong and multiple interlinkages and no linkages at all. Rising temperatures and falling river levels are linked in appropriately signed ways to centralization/fragmentation. ${ }^{33}$ Climate deterioration led to Mesopotamian fragmentation. It may also be true that Mesopotamian centralization facilitated climate deterioration in the less direct sense that stronger political hierarchies probably accelerated deforestation and surely encouraged over-irrigation. Interestingly, though, there are few other linkages across the blocs of indicators. Economic

33. This finding goes against Cowgill's (I988:26I) earlier verdict that "there is little or no evidence that [long-term environmental changes].... were important [to accounting for political fragmentation]." 
Table 3 - Statistically Significant Mesopotamian Relationships (bivariate

\section{logit analyses)}

\begin{tabular}{|c|c|c|c|}
\hline Relationship & $\begin{array}{l}\text { Coefficient } \\
\text { (std. error) }\end{array}$ & Relationship & $\begin{array}{l}\text { Coefficient } \\
\text { (std. error) }\end{array}$ \\
\hline $\begin{array}{l}\text { Centralization/fragmentation } \\
\text { Urban population }\end{array}$ & $\begin{array}{l}-.006^{* *} \\
(.003)\end{array}$ & $\begin{array}{l}\text { Economic contraction } \\
\text { Hinterland incursions }\end{array}$ & $\begin{array}{l}2.813^{* *} \\
(.606)\end{array}$ \\
\hline $\begin{array}{l}\text { Centralization/fragmentation } \\
\text { Rising temperature }\end{array}$ & $\begin{array}{c}-1.621^{* *} \\
(.501)\end{array}$ & $\begin{array}{l}\text { Economic contraction } \\
\text { Trade collapse }\end{array}$ & $\begin{array}{l}2.430^{* *} \\
(.605)\end{array}$ \\
\hline $\begin{array}{l}\text { Centralization/fragmentation } \\
\text { River levels }\end{array}$ & $\begin{array}{l}.354^{* *} \\
(.158)\end{array}$ & $\begin{array}{l}\text { Economic contraction } \\
\text { Rising temperature }\end{array}$ & $\begin{array}{l}1.799 * * \\
(.595)\end{array}$ \\
\hline $\begin{array}{l}\text { Centralization/fragmentation } \\
\text { Economic contraction }\end{array}$ & $\begin{array}{l}-1.036^{* *} \\
(.444)\end{array}$ & $\begin{array}{l}\text { Economic contraction } \\
\text { River levels }\end{array}$ & $\begin{array}{l}-.555^{* *} \\
(.202)\end{array}$ \\
\hline $\begin{array}{l}\text { Imperial size } \\
\text { River levels }\end{array}$ & $\begin{array}{l}-.537 * * \\
(.185)\end{array}$ & $\begin{array}{l}\text { Hinterland incursions } \\
\text { Trade collapse }\end{array}$ & $\begin{array}{l}\text { not calculable } \\
\text { (see below) }\end{array}$ \\
\hline $\begin{array}{l}\text { Imperial size } \\
\text { Climate interaction }\end{array}$ & $\begin{array}{c}-1.301^{* *} \\
(.613)\end{array}$ & $\begin{array}{l}\text { Hinterland incursions } \\
\text { Regime transition }\end{array}$ & $\begin{array}{r}1.247^{*} \\
(.714)\end{array}$ \\
\hline $\begin{array}{l}\text { Urban population } \\
\text { Economic contraction }\end{array}$ & $\begin{array}{l}-.007 * * \\
(.003)\end{array}$ & $\begin{array}{l}\text { Hinterland incursions } \\
\text { Climate interaction }\end{array}$ & $\begin{array}{l}1.684^{* *} \\
(.495)\end{array}$ \\
\hline $\begin{array}{l}\text { Urban population growth rate } \\
\text { Rising temperature (b) }\end{array}$ & $\begin{array}{l}-4.859 * * \\
(2.052)\end{array}$ & $\begin{array}{l}\text { Trade collapse } \\
\text { Regime transition }\end{array}$ & $\begin{array}{l}1.498^{* *} \\
(.719)\end{array}$ \\
\hline \multirow[t]{6}{*}{$\begin{array}{l}\text { Urban population growth rate } \\
\text { Hinterland incursions }\end{array}$} & $\begin{array}{l}-4.508^{* *} \\
(2.036)\end{array}$ & $\begin{array}{l}\text { Trade collapse } \\
\text { River levels }\end{array}$ & $\begin{array}{c}-1.199 * * \\
(.365)\end{array}$ \\
\hline & & $\begin{array}{l}\text { Trade collapse } \\
\text { Rising Temperature (b) }\end{array}$ & $\begin{array}{l}-.123^{*} \\
(.071)\end{array}$ \\
\hline & & $\begin{array}{l}\text { Trade collapse } \\
\text { Climate interaction }\end{array}$ & $\begin{array}{l}2.120^{* *} \\
(.527)\end{array}$ \\
\hline & & $\begin{array}{l}\text { Regime transition } \\
\text { Climate interaction }\end{array}$ & $\begin{array}{r}1.306^{*} \\
(.715)\end{array}$ \\
\hline & & $\begin{array}{l}\text { Hinterland incursions } \\
\text { River levels }\end{array}$ & $\begin{array}{c}-1.097^{* *} \\
(.332)\end{array}$ \\
\hline & & $\begin{array}{l}\text { Rising Temperature } \\
\text { River levels }\end{array}$ & $\begin{array}{l}-.553^{* *} \\
(.174)\end{array}$ \\
\hline
\end{tabular}

Note: $\mathrm{N}=96$

* Denotes statistical significance at the .10 level or better.

** Denotes statistical significance at the .05 level or better. The hinterland incursionstrade collapse relationship could not be calculated in logit because of a lack of variance. All periods of trade collapse were also periods of hinterland incursion. A strong positive relationship can be demonstrated in cross-tabulated form.
Table 4 - Two Multivariate Logit Analyses of Mesopotamian Centralization/ Fragmentation and Political-Economic Crisis

\begin{tabular}{lcc}
\hline $\mathbf{N}=\mathbf{9 6}$ & Centralization/Fragmentation & Political-Economic Crisis \\
\hline Constant & $2.56^{* *}$ & $-6.196^{* *}$ \\
& $(.807)$ & $(1.643)$ \\
Urban Population & $-.012^{* *}$ & -.005 \\
& $(.004)$ & $(.005)$ \\
Economic Contraction & $-1.632^{* *}$ & $2.824^{* *}$ \\
& $(.672)$ & $(.748)$ \\
Hinterland Incursions & .306 & - \\
& $(.684)$ & -1.297 \\
Temperature & $-1.732^{* *}$ & $(1.021)$ \\
& $(.616)$ & $-1.808^{* *}$ \\
River Levels & -.236 & $(.468)$ \\
Likelihood Ratio Chi Square & $(.239)$ & $57.59^{* *}$ \\
Pseudo R-square & $24.57^{* *}$ & .447 \\
\hline
\end{tabular}

contraction and urban population size are significantly and negatively related. Economic contractions are also linked negatively to centralization/fragmentation. The urban population growth rate is negatively linked to rising temperatures and to hinterland incursions. Aside from the positive relationships between Taagapera's imperial size measure (strongly biased toward the Akkadian expansion) and the level of the Tigris/Euphrates rivers and the interaction effect of rising temperature and dwindling river levels, there are no other significant or systematic linkages.

The overall impression one gleans from the bivariate outcomes is that of two sets of processes (centralization and urbanization versus political-economic crisis) at work that are mediated by a third block of variables (temperature, river levels, and economic contraction) with linkages to both of the other two blocks. Separate multivariate analyses of centralization/fragmentation and politicaleconomic crisis provide additional support for this interpretation. Table 4 summarizes a multivariate outcome for centralization/fragmentation that links it negatively to temperature, economic contraction, and urban population size. Since these variables are capable of accounting for less than 20 percent of the variance, there is much left to be explained. In the same table, crisis is shown as being connected significantly to river levels (negatively) and economic contraction (positively). The near 45 percent predictive power of this equation is certainly more persuasive than in the case of the other dependent variable focus. 
Table 5 - The Timing of Selected Mesopotamian Processes

\begin{tabular}{cclc}
\hline $\begin{array}{c}\text { Hinterland } \\
\text { Incursions }\end{array}$ & Trade Collapse & $\begin{array}{l}\text { Negative Urban } \\
\text { Growth }\end{array}$ & Fragmentation \\
\hline $3200-3000$ & $3200-3000$ & & $3200-2350$ \\
$2200-2000$ & $2200-2000$ & $2500-2200$ & \\
& & $2100-1700$ & $2150-2100$ \\
$1600-1500$ & & $2000-1760$ \\
$1200-1000$ & $1200-1000$ & $1600-1500$ & $1595-1415$ \\
\hline
\end{tabular}

Yet note that urban population size is significant only for centralization/fragmentation. It does not appear to influence political-economic crises. The crises, on the other hand, do not appear to influence urbanization and centralization/ fragmentation. Two different dynamics seem to be operative.

The statistical outcome would seem to support Tainter's disdain for traditional explanations of decline and disorder. The political-economic crises certainly occur and do so in a repetitive fashion but they do not seem to correlate systematically with other societal problems (for instance, population decline and the fragmentation of order). Thus, either the prevalence of political-economic crises is largely independent of other, more fundamental, entropic processes or the interaction of these crises with the other entropic processes is more complicated than can be captured readily by bivariate regression analyses. If forced to choose between these stark alternatives, my own predilection is to prefer the latter interpretation over the former.

Table 5 is suggestive in this regard. Statistically significant relationships require a considerable amount of overlap in the timing of the multiple processes at work. If phenomenon $\mathrm{A}$ sometimes precedes phenomenon $\mathrm{B}$ and at other times A overlaps or follows B, the likelihood of a statistically significant linear relationship is decreased. But what if substantively we suspect that hinterland incursions can sometimes facilitate fragmentation and/or sometimes be encouraged by fragmentation. Does that mean that there is no systematic relationship between hinterland incursions and fragmentation? No, what it means is that the evidence does not support a strong causal link from hinterland incursions to fragmentation. That would approximate Tainter's position giving explanatory superiority to his diminishing marginal returns thesis. Yet it still falls short of saying that fragmentation and hinterland incursions are unrelated.

Table 5 lays out the rough periodicity of some of the processes at stake in this analysis. Quantitative analysis places a premium on relatively precise syn- chronicity. That is, ideally, hinterland incursions, say, would be exactly coterminous with negative urban growth and fragmentation. This is not observed in ancient Mesopotamian history. Instead, one finds spikes of political-economic crises sometimes in the incipient phases of negative urban growth and fragmentation and sometimes following a period of negative urban growth and fragmentation. But the crises are rarely exactly coterminous with the more protracted indicators of entropic decay.

Because the two clusters of problems seem better linked than the logit analyses reveal, we should probably be reluctant to accept the empirical outcome fully at face value. It would be wrong to insist that $\mathrm{X}$ is a cause of $\mathrm{Y}$ despite all the quantitative evidence to the contrary. What seems more likely is that the cause and effect relationships are more complex than the contention that $\mathrm{X}$ is always or usually a cause of $Y$ can match. We are left instead with the more awkward conclusion that X (political-economic crises) and $\mathrm{Y}$ (fragmentation) may be related reciprocally but not significantly. $X$ sometimes contributes to the probability of $\mathrm{Y}$; sometimes $\mathrm{Y}$ contributes to the probability of $\mathrm{X}$.

Despite the ambiguities associated with some of these findings, we are still in a better explanatory position than arguing verbally incessantly over whether barbarians, trade collapses, and climate matter. They matter but not necessarily as prime movers. Some of them, however, are more central to the problem of recurring order and disorder than others. Climate deterioration, for instance, appears to have been crucial and pervasive to Mesopotamian decline. It seems also to have been the common denominator in the whole array of social, political, and economic problems. Diminishing marginal returns-assuming urban population fluctuations capture this phenomenon reasonably well-if not a common denominator appears to have been critical to centralization and fragmentation-and precisely as our interpretation of Tainter's theory predicts. Incursions, trade interruptions, economic contractions, and regime transitions certainly did not help. At times, they no doubt made matters worse even when they were less than principal causal factors.

One final caveat is inescapable. Performing logit analysis on ancient data is all well and good. Executing such analyses, however, assumes that the data have some validity. We need not assume that they capture perfectly what they purport to measure. That is too high a bar to sustain. We must assume, though, that they bear some reasonable correspondence to both the ancient processes and the theory under scrutiny. To the extent that this assumption is not borne out by subsequent analyses, the value of the current analysis will be accordingly depreciated. For instance, our estimates of urban population may or may not stand up as reasonable indicators of fluctuations in Mesopotamian city populations. In turn, the urbanization data may or may not stand up as proxy 
indicators of marginal returns on societal investments. We now know that that there was a negative relationship between urban population size and centralization/fragmentation. That may mean that more people led to an increased likelihood of fragmentation in Mesopotamia. But it could also suggest that declining urban populations led to increased efforts at centralization. ${ }^{34}$

There are two alternatives. One, we can await the emergence of unchallengeable data. For ancient questions, it is doubtful that that day will ever come. In the interim, we need to work with what we can, as best we can. Two, empirical answers to our theoretical questions should be treated as highly preliminary responses to complicated questions. They most definitely will not be the last word on the subject of Mesopotamian complexification. Any inadequacies or puzzling outcomes manifested in this analysis should encourage others to try their own hand at doing it better-both for Mesopotamia and other places in which political order tends to wax and wane.

\section{REFERENCES}

Adams, Robert McC. I974. "Historic Patterns of Mesopotamian Irrigation Agriculture." In Irrigation's Impact on Society, edited by Theodore M. Downing and McGuire Gibson. University of Arizona Anthropological Papers, no. 25. Tucson: University of Arizona Press.

. 1978. "Strategies of Maximization, Stability, and Resilience in

Mesopotamina Society, Settlement, and Agriculture." Proceedings of the

American Philosophical Society I22:329-35. 198I. Heartland of Cities. Aldine: Chicago.

. I988. "Contexts of Civilizational Collapse: A Mesopotamian View." In

The Collapse of Ancient States and Civilizations, edited by N. Yoffee and G. L.

Cowgill. Tucson: University of Arizona Press.

Algaze, Guillermo. 1986. "Kurban Hoyuk and the Late Chalcolithic Period in the

Northeast Mesopotamian Periphery: A Preliminary Assessment." In Gamdat

Nasr: Period or Regional Style?, edited by Uwe Finkbeiner and Wolfgang Rollig.

Weisbaden: Dr. Ludwig Reichert Verlag. - 1993. The Uruk World System: The Dynamics of Expansion of Early

Mesopotamian Civilization. Chicago: University of Chicago Press. . 200I. "Initial Social Complexity in Southwest Asia: The Mesopotamian

Advantage." Current Anthropology 42:199-233.

34. At a 2004 Santa Fe Institute presentation of the findings, Robert McC. Adams, for instance, strongly preferred the latter interpretation of the two.
Algaze, Guillermo, T. D’Altroy, M. Fragipane, H. Nissen, H. Pittman, S. Pollock, M. Rothman, G. Schwartz, Gil Stein, and Henry Wright. I998. "School of American Research Advanced Seminar: Mesopotamia in the Era of State Formation" (http://www.science.widener.edu/ssci/Mesopotamia).

Baines, J. and Norman Yoffee. 1998. "Order, Legitimacy, and Wealth in Ancient Egypt and Mesopotamia." In Archaic States, edited by Gary M. Feinman and Joyce Marcus. Santa Fe, NM: School of American Research Press.

Bell, Barbara. 197I. "The Dark Ages in Ancient History I: The First Dark Age in Egypt." American Journal of Archaeology 75:1-26. . I975. "Climate and the History of Egypt: The Middle Kingdom." American Journal of Archaeology 79:223-69.

Bottema, S. 1997. "Third Millennium Climate in the Near East Based upon Pollen Evidence." In Third Millennium BC Climate Change and Old World Collapse, edited by H. N. Dalfes, G. Kukla, and H. Weiss. Berlin: Springer.

Bowden, M. J., R. W. Kates, P. A. Kay, W. E. Riebsame, R. A. Warrick, D. L. Johnson, H. A. Gould, and D. Weiner. 198I. "The Effect of Climate Fluctuations on Human Populations: Two Hypotheses." In Climate and History: Studies in Past Climates and Their Impact on Man, edited by T. M. Wigley, M. J. Ingram, and G. Farmer. Cambridge: Cambridge University Press.

Bronson, Bennet. I988. "The Role of Barbarians in the Fall of States." In The Collapse of Ancient States and Civilizations, edited by N. Yoffee and G. L. Cowgill. Tucson: University of Arizona Press.

Buccellati, Giorgio. 1966. The Amorites of the Ur III Period. Naples: Instituto Orientale de Napoli.

Butzer, K.W. 1976. The Early Hydraulic Civilization in Egypt: A Study in Cultural Ecology. Chicago: University of Chicago Press.

. 1995. "Environmental Change in the Near East and Human Impact on the Land." In Civilizations of the Ancient Near East, Vol. I, edited by J. M. Sasson. New York: Simon and Schuster.

. I997. "Sociopolitical Discontinuity in the Near East C. 2200 ВСЕ: Scenarios from Palestine and Egypt." In Third Millennium вC Climate Change and Old World Collapse, edited by H. N. Dalfes, G. Kukla and H. Weiss. Berlin: Springer.

Chandler, Tertius. 1987. Four Thousand Years of Urban Growth: An Historical Census. Lewiston, NY: Edwin Mellen Press.

Charvat, Petr. 2002. Mesopotamia Before History. London: Routledge.

Chase-Dunn, Christopher, Alexis Alvarez, Dan Pasciuti, and Thomas D. Hall. 2002. "Power and Size: Urbanization and Empire Formation in World-Systems." Paper presented at the annual meeting of the International Studies Association, New Orleans, La., February.

Chew, Sing C. 1999. "Ecological Relations and the Decline of Civilizations in the Bronze Age World System: Mesopotamia and Harappa 2500-I700 B.C.." In Ecology and the World-System, edited by W. L. Goldfrank, D. Goodman, and A. Szasz. Westport, CT: Greenwood Press. 
200I. World Ecological Degradation: Accumulation, Urbanization and Deforestation, 3000 BC-AD 2000. Walnut Creek, CA: Altamira.

Cipolla, Carlo. I970. The Economic Decline of Empires. London: Methuen.

Courty, M-A, and H. Weiss. I997. "The Scenario of Environmental Degradation in the Tell Leilan Region, NE Syria, During the Late Third Millennium Abrupt Climate Change." In Third Millennium вс Climate Change and Old World_ Collapse, edited by H. N. Dalfes, G. Kukla, and H. Weiss. Berlin: Springer.

Cowgill, George L. I988. "Onward and Upward with Collapse." In The Collapse of Ancient Civilizations, edited by N. Yoffee and G. L. Cowgill. Tucson: University of Arizona Press.

Culbert, T. Patrick. I988. "The Collapse of Classic Maya Civilization." In The Collapse of Ancient States and Civilizations, edited by N. Yoffee and G. L. Cowgill. Tucson: University of Arizona Press.

Dewar, R. and Henry Wright. 1993. "The Culture History of Madagascar." Journal of World Prehistory 7:417-66.

Diakonoff, I. M. I969. "The Rise of the Despotic State in Ancient Mesopotamia." In Ancient Mesopotamia: Socio-economic History, edited by I. M. Diakonoff. Moscow: Nauka Publishing House.

Diester-Haass, L. I973. "Holocene Climate in the Persian Gulf as Deduced from Grain Size and Pteropod Distribution." Marine Geology 14:207-23.

Edzard, Dietz O. I967a. "The Old Babylonian Period." In The Near East: The Early Civilizations, edited by Jean Bottero, Elena Cassin, and Jean Vercoutter. New York: Delacorte Press.

. I967b. "The Third Dynasty of Ur-Its Empire and Its Successor States." In The Near East: The Early Civilizations, edited by J. Bottero, E. Cassin, and J. Vercoutter. New York: Delacorte Press.

Ekholm, Kajsa. 1980. "On the Limits of Civilization: The Structure and Dynamics of Global Systems.” Dialectical Anthropology 5:155-66.

Erinc, S. 1978. "Changes in the Physical Environment in Turkey Since the End of the Last Glacial." In The Environmental History of the Near and Middle East Since the Last Ice Age, edited by W. C. Brice. London: Academic Press.

Fairbridge, R., O. Erol, M. Karaca, and Y. Yilmaz. I997. "Background to MidHolocene Climate in Anatolia and Adjacent Regimes." In Third Millennium BC Climate Change and Old World Collapse, edited by H. N. Dalfes, G. Kukla, and H. Weiss. Berlin: Springer.

Fairservis, W. A., Jr. I992. "The Development of Civilization in Egypt and South Asia: A Hoffman-Fairservis Dialectic." In The Followers of Horus: Studies Dedicated to Michael Allen Hoffman, 1944-1990, edited by R. Friedman and B. Adams. Oxford: Oxbow Books.

Frank, Andre Gunder and William R. Thompson. Forthcoming. "Bronze Age Economic Contraction and Expansion Revisited." In Journal of World History. Paper delivered at the American Schools of Oriental Research, Toronto, Canada, November 2002 .
Gasche, H., J. A. Armstrong, S. W. Cole, and V. G. Gurzadyan. 1998. Dating the Fall of Babylon: A Reappraisal of Second-Millennium Chronology. Ghent, Belgium and Chicago, IL: University of Ghent and the Oriental Institute of the University of Chicago.

Gibson, McGuire. 1974. "Violation of Fallow and Engineered Disaster in Mesopotamian Civilization." In Irrigation's Impact on Society, edited by Theodore M. Downing and McGuire Gibson. University of Arizona Anthropological Papers, no. 25. Tucson: University of Arizona Press.

Gilpin, Robert. I98I. War and Change in World Politics. New York: Cambridge University Press.

Hoffman, Michael A. 1979. Egypt Before the Pharaohs: The Prebistoric Foundations of Egyptian Civilization. New York: Alfred A. Knopf.

Hole, Frank. 1994. "Environmental Instabilities and Urban Origins." In Early States in the Near East: The Organizational Dynamics of Complexity, edited by Gil Stein and M. S. Rothman. Madison, WI: Prehistory Press.

Jacobsen, Thorkild and Robert McC. Adams. 1958. "Salt and Silt in Ancient Mesopotamian Agriculture." Science I28:125I-8.

Joffe, A. H. 2000. "Egypt and Syro-Mesopotamia in the 4th Millennium: Implications of the New Chronology." Current Anthropology 4I:II3-23.

Kaufman, Herbert. I988. "The Collapse of Ancient States and Civilizations as an Organizational Problem." In The Collapse of Ancient States and Civilizations, edited by N. Yoffee and G. L. Cowgill. Tucson: University of Arizona Press.

Kay, P. A. and D. L. Johnson. I98I. "Estimated Tigris-Euphrates Stream Flow from Regional Paleoenvironmental Proxy Data." Climatic Change 3:25I-63.

Kerr, R. A. 1998. "Sea-Floor Dust Shows Drought Felled Akkadian Empire." Science $279 \div 325-26$.

Lemcke, G. and M. Sturm. I997. "[Actual symbol not reproducible] and Trace Element Measurements as Proxy for the Reconstruction of Climate Changes at Lake Van (Turkey): Preliminary Results." In Third Millennium вс Climate Change and Old World Collapse, edited by H. N. Dalfes, G. Kukla, and H. Weiss. Berlin: Springer.

Lupton, Alan. 1996. The Stability of Change: Socio-political Development in North Mesopotamia and Southeast Anatolia, 4000-2700 BC. Oxford: British Archaeological Reports.

Maekawa, Kazuya. 1984. "Cereal Cultivation in the Ur III Period." Bulletin of Sumerian Agriculture I:73-96.

Marcus, Joyce. I998. "The Peaks and Valleys of Ancient States: An Extension of the Dynamic Model." In Archaic States, edited by G. M. Feinman and Joyce Marcus. Santa Fe, NM: School of American Research Press.

Matthews, Rogers. 2003. The Archaeology of Mesopotamia: Theories and Approaches. London: Routledge.

McEvedy, Colin and Richard Jones. 1978. Atlas of World Population History. New York: Facts on File. 
Michalowski, Piotr. 1989. The Lamentation over the Destruction of Sumer and Ur. Winona Lake, IN: Eisenbrauns.

Modelski, George. 2003. World Cities, -3000 to 2000. Washington, D.C.: Faros 2000. Neumann, J. and R.M. Sigrist. 1978. "Harvest Dates in Ancient Mesopotamia as Possible Indicators of Climate Variations." Climate Change I:239-52.

Nissen, H.J. 1988. The Early History of the Ancient Near East, 9000-2000 BC, translated by E. Lutzeier with K. J. Northcott. Chicago: University of Chicago Press.

Oates, D. and Joan Oates. I977. "Early Irrigation Agriculture in Mesopotamia." In Problems in Economic and Social Archaeology, edited by G. DeG. Siveking, I. H. Longworth, and K. E. Wilson. London: Duckworth.

Oates, Joan. 1979. Babylon. London: Thames and Hudson.

Postgate, J. Nicholas. 1977. The First Empires. Oxford: Elsevier. . I992. Early Mesopotamia: Society and Economy at the Dawn of History. New York: Routledge.

Potts, Timothy. 1994. Mesopotamia and the East: An Archaeological and Historical Study of Foreign Relations, Ca. 3400-2000 BС. Oxford: Oxford University Committee for Archaeology.

. 1997. Mesopotamian Civilization: The Material Foundations. Ithaca, NY: Cornell University Press.

Rasler, Karen and William R. Thompson. 1994. The Great Powers and Global Struggle, 1490-1990. Lexington: University Press of Kentucky.

Redman, Charles L. I999. Human Impact on Ancient Environments. Tucson: University of Arizona Press.

Rothman, Mitchell S., ed. 200I. Uruk Mesopotamia E Its Neighbors: Cross-Cultural Interactions in the Era of State Formation. Santa Fe, NM: School of American Research Press.

Schoell, M. 1978. "Oxygen Isotope Analysis on Authigenic Carbonates from Lake Van Sediments and Their Possible Bearing on the Climate of the Past 10000 Years." In The Geology of Lake Van, edited by E.T. Degens and F. Kurtman. Ankara: The Mineral Research and Exploration Institute of Turkey.

Sherratt, A. I996. "Sedentary Agricultural and Nomadic Pastoral Populations (3000-700 BC)." In History of Humanity: From the Third Millennium to the Seventh Century BC, edited by A. H. Dani and J.-P. Mohen. London: Routledge.

Speiser, Ephraim A. 1952. "Some Factors in the Collapse of Akkad." Journal of the American Oriental Society 72:97-IOI.

Spier, Fred. 1996. The Structure of Big History from the Big Bang until Today. Amsterdam: Amsterdam University Press.

Stein, Gil. 1999. Rethinking World-Systems: Diasporas, Colonies and Interaction in Uruk Mesopotamia. Tucson: University of Arizona Press.

Taagapera, Rein. 1978a. "Size and Duration of Empires: Systematics of Size." Social Science Research 7:108-27.

I978b. "Size and Duration of Empires: Growth-Decline Curves, 3000 вС to 600 вC." Social Science Research 7:180-96.
Tainter, Joseph A. 1988. The Collapse of Complex Societies. Cw2sq. 2000. "Global Change, History, and Sustainability." In The Way the Wind Blows: Climate, History, and Human Action, edited by Roderick J. McIntosh, Joseph A. Tainter, and Susan K. McIntosh. New York: Columbia University Press.

Thompson, William R. 20oIa."The Globalization of Ancient Near Eastern Trade," Paper delivered at the annual meeting of the American Schools of Oriental Research, Boulder, Co., November. 200Ib. "Trade Collapse and Diffusion," Paper delivered at the annual meeting of the International Studies Association, Chicago, Illinois, February. . 2002. "Testing a Cyclical Instability Theory in the Ancient Near East." Comparative Civilizations Review 46:34-78.

. Forthcoming-a. "Climate, Water and Political-economic Crises in the Southwest Asian Bronze Age." In World System/Earth System Dynamics: Modelling Socio-Ecological Systems, edited by Carole Crumley and Christian Isendahl.

Forthcoming-b. "Early Globalization, Trade Crises and Reorientations in the Ancient Near East." In Connectivity in Antiquity: Globalization as Long-term Historical Process, edited by Oystein S. LaBianca and Sandra Scham. New York: Continuum.

Van De Mieroop, Marc. 2004. A History of the Ancient Near East, ca. 3000-323 BC. Malden, MA: Blackwell.

Van Zeist, W. and S. Bottema. I977. "Palynological Investigations in Western Iran." Palaeobistoria $\mathrm{I} 7: 19-85$.

Van Zeist, W. and H. Woldring. 1978. "A Postglacial Pollen Diagram from Lake Van in East Anatolia." Review of Palaeobotany and Palynology 26:249-76.

Weiss, H. 2000. "Beyond the Younger Dryas: Collapse as Adaptation to Abrupt Climate Change in Ancient West Asia and the Eastern Mediterranean." In Environmental Disaster and the Archaeology of Human Response, edited by G. Bawden and R. M. Reycraft. Albuquerque, NM: Maxwell Museum of Anthropology, University of New Mexico.

Weiss, H. and M.-A. Courty. I993. "The Genesis and Collapse of the Akkadian Empire." In Akkad: The First World Empire, edited by M. Liverani. Padua, Italy: Sargon.

Weiss, H., M.-A. Courty, W. Wetterstrom, F. Guichard, L. Senior, R. Meadow, A. Curnow. 1993. "The Genesis and Collapse of Third Millennium North Mesopotamian Civilization." Science 261:995-1004.

Whitmore, Thomas M., B.L. Turner II, Douglas L. Johnson, Robert W. Kates, and Thomas R. Gottschang. I990. "Long-Term Population Change." In The Earth as Transformed by Human Action: Global and Regional Changes in the Biosphere over the Past 300 Years, edited by B.L. Turner II, William C. Clark, Robert W. Kates, John F. Richards, Jessica T. Mathews, and William B. Meyer. Cambridge: Cambridge University Press. 
Wright, Henry T. 20or. "Cultural Action in the Uruk World." In Uruk Mesopotamia $\mathcal{E}$ Its Neighbors, edited by Mitchell S. Rothman. Santa Fe, NM: School of American Research Press.

Yoffee, Norman. 1979. "The Decline and Rise of Mesopotamian Civilization." American Antiquity 44:5-35.

1988. "The Collapse of Ancient Mesopotamian States and Civilization." In The Collapse of Ancient States and Civilizations, edited by N. Yoffee and G. L. Cowgill. Tucson: University of Arizona Press. 